\title{
A RECONSTRUCTION OF CHRONIC DOSE EQUIVALENTS \\ FOR RONGELAP AND UTIRIK RESIDENTS - 1954 TO 1980
}

\author{
E.T. Lessard, N.A. Greenhouse, AND R.P. Miltenberger
}

October 1980

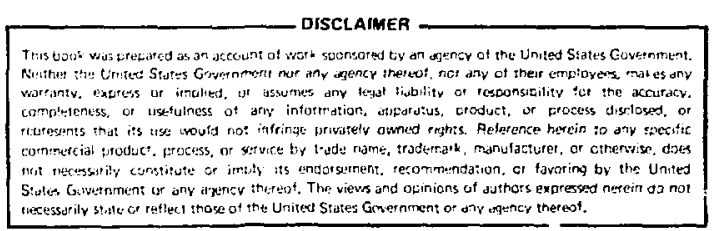

SAFETY AND ENVIRONMENTAL PROTECTION DIVISION 
A RECONSTRUCTION OF CHRONIC DOSE EQUIVALENTS FOR RONGELAP AND UTIRIK RESIDENTS - 1954 TO 1980

E. T. Lessard, N. A. Greenhouse, R. P. Miltenberger

\begin{abstract}
From June 1946 to August 1958, the U.S. Department of Defense and Atomic Energy Commission conducted nuclear weapons tests in the Northern Marshall Islands. BRAVO, an aboveground test in the Castle series, resulted in radioactive fallout contaminating Rongelap and Utirik Atolls. On March 3, 1954, the inhabitants of these atolls were relocated until radiation exposure rates declined to acceptable levels. Environmental and personnel radiological monitoring programs were begin in the mid 1950's by Brookhaven National Laboratory to ensure that dose equivalents received or committed remained within U.S. Federal Radiation Council Guidelines for members of the general public. Body burden and dose equivalent histories along with activity ingestion patterns post return are presented. Dosimetric methods, results, and internal dose equivalent distributions for subgroups of the population are also described.
\end{abstract}




\section{INTRODUCTION}

On March 1, 1954, at Bikini Ato11, BRAVO, the first of six nuclear weapons tests in the Castle series, was detonated. The BRAVO device caused substantial surface contamination on inhabited atolls within a 2,000 square mile area. The contaminated region was cigar shaped and included Ailinginae, Rongelap, Rongerik, and Utirik Atolls which lay east of ground zero at distances from 60 to 300 miles. The fallout on Rongelap, initially visible at H+6 hours, had thinned out to the extent that it was no longer seen at $\mathrm{H}+10$ hours (G162).

On March 3, 1954, the 64 residents of Ronge lap Ato 11 and 18 residents of Sifo Island, Ailinginae Ato11, were evacuated. On March 3 and 4, evacuation of 157 Utirik Atoll residents also took place. During the first few weeks and at least once every year from 1957 to the present, a Brookhaven National Laboratory medical team, organized by the Department of Defense and by the Atomic Energy Commission and its successor organizations, has provided meaical examinations to monitor the health of the persons initially affected by the fallout from the nuclear testing program, plus a comparison population. Reports of their findings are given in $\operatorname{Cr} 56, \operatorname{Co} 58, \operatorname{Co} 59, \operatorname{Co} 60, \operatorname{Co6} 2, \operatorname{Co63}, \operatorname{Co} 65, \operatorname{Co} 67, \operatorname{Co} 70, \operatorname{Co} 75$, and Co80.

The Utirikese and Rongelapese returned to their home atolls in June 1954 and in June 1957 respectively. The earlier repatriation of Utirik Atoll was based on the low level of external radiation exposure measured after the initial 3 month observation period (March to June 1954). The Utirik population was not examined by a Brookhaven medical teain until March, 1957, when 144 people received comprehensive physical examinations. Following the 1957, medical survey, two men, removed from Utirik for medical reasons, were whole body counted at Argonne National Laboratory and provided urine samples for radiochemical anal- 
ysis of ${ }^{137} \mathrm{Cs}$. Four persons visited Argonne from Rongelap and, in addition, pooled urine samples from both atolls were analyzed radiochemically for ${ }^{137} \mathrm{Cs}$ and ${ }^{90} \mathrm{Sr}$. Subsequent Brookhaven National Laboratory expeditions by members of the Medical Department and Safety and Environmental Protection Division utilized whole body counting and radiochemical analysis of urine and blood samples to identify and quantify the radionuclides that were present in the body. The results of these radiological measurements are given in terms of body burden in Tables 1 and 2 . Throughout this paper the units of quantities are SI derived and those which are accepted for use with the SI for the time being. Thus both the Curie and the Becquerel may be used as units for the quantity activity. The aforementioned body burden tables illustrate adult mean values for Rongelap and Utirik. An adu1t, as classified here, was a person over 16 years of age. The mean body mass in this age interval was 60 kilograms. The cbserved body mass versus age distribution is shown in Figure 1 for Rongelap residents. The same body mass versus age distribution was observed at Utirik.

Because of the paucity of measurements at Utirik, information on ${ }^{60} \mathrm{Co}$, ${ }^{65} \mathrm{Zn}$, and ${ }^{55} \mathrm{Fe}$ was in some instances derived from the ratio of adult mean body burdens between Rongelap and Utirik. A mean ratio of 2.6 was observed in body burdens for ${ }^{65} \mathrm{Zn},{ }^{90} \mathrm{Sr}$, and ${ }^{137} \mathrm{Cs}$ after they reached their maximum values. The standard deviation of this ratio was $15 \%$.

In the following analysis, personal body burden histories and residence intervals, in conjunction with contemporary dosimetric models, are used to estimate internal dose. Dosimetric distributions were constructed from the results and a sumary of the derived activity ingestion rates and dose equivalents was provided for various subgroups of the population. Additionally, exposure rate history curves were constructed for each atoll for the period following the 
Table 1

Ronge lap Body Burdens

\begin{tabular}{|c|c|c|c|c|c|c|c|}
\hline & \multicolumn{2}{|c|}{ Adult Males } & \multicolumn{2}{|c|}{ Adult Fenales } & \multicolumn{2}{|c|}{ Adults } & \multirow[b]{2}{*}{$\begin{array}{c}\text { Days Post } \\
\text { Return } \\
\text { Days }\end{array}$} \\
\hline & $\begin{array}{l}\text { Body } \\
\text { Burder: } \\
\text { HCi }\end{array}$ & $\begin{array}{c}\text { Munber } \\
\text { of } \\
\text { Persons }\end{array}$ & $\begin{array}{l}\text { Body } \\
\text { Burden } \\
\text { HCi }\end{array}$ & $\begin{array}{c}\text { Muber } \\
\text { of } \\
\text { Persons }\end{array}$ & $\begin{array}{l}\text { Body } \\
\text { Burden } \\
\text { uCi }\end{array}$ & $\begin{array}{l}\text { Muber } \\
\text { of } \\
\text { Persons }\end{array}$ & \\
\hline${ }^{60} \mathrm{Co}$ & $\begin{array}{l}2.9 \times 10^{-5} \\
1.0 \times 10^{-2} \\
2.5 \times 10^{-3}\end{array}$ & $\begin{array}{l}\text { Mh } \\
37 \\
45\end{array}$ & $\begin{array}{l}1.7 \times 10^{-5} \\
7.8 \times 10^{-3} \\
2.0 \times 10^{-3}\end{array}$ & $\begin{array}{l}M \\
37 \\
45\end{array}$ & $\begin{array}{l}2.3 \times 10^{-5} \\
9.0 \times 10^{-3} \\
2.2 \times 10^{-3}\end{array}$ & $\begin{array}{l}\mathrm{M} \\
74 \\
90\end{array}$ & $\begin{array}{r}1 \\
1370 \\
2831\end{array}$ \\
\hline${ }^{65} \mathrm{Zn}$ & $\begin{array}{l}4.3 \times 10^{-2} \\
4.3 \times 10^{-1} \\
6.2 \times 10^{-1} \\
9.5 \times 10^{-2}\end{array}$ & $\begin{array}{l}M A \\
30 \\
32 \\
38\end{array}$ & $\begin{array}{l}3.8 \times 10^{-2} \\
3.8 \times 10^{-1} \\
5.0 \times 10^{-1} \\
8.5 \times 10^{-2}\end{array}$ & $\begin{array}{l}\mathrm{Nh} \\
12 \\
27 \\
23\end{array}$ & $\begin{array}{l}4.1 \times 10^{-2} \\
4.1 \times 10^{-1} \\
5.6 \times 10^{-1} \\
5.0 \times 10^{-2}\end{array}$ & $\begin{array}{l}M \\
42 \\
59 \\
61\end{array}$ & $\begin{array}{r}1 \\
304 \\
639 \\
1370\end{array}$ \\
\hline${ }^{55} \mathrm{Fe}$ & $4.3 \times 10^{-1}$ & 28 & $4.0 \times 10^{-1}$ & 32 & $4.1 \times 10^{-1}$ & 60 & 4626 \\
\hline${ }^{90} \mathrm{Sr}$ & $\begin{array}{l}1.9 \times 10^{-4} \\
3.7 \times 10^{-3} \\
5.7 \times 10^{-3} \\
3.7 \times 10^{-3} \\
8.8 \times 10^{-3} \\
7.9 \times 10^{-3} \\
2.8 \times 10^{-3} \\
3.9 \times 10^{-3} \\
4.1 \times 10^{-3} \\
1.3 \times 10^{-3} \\
3.1 \times 10^{-3} \\
2.0 \times 10^{-3} \\
6.6 \times 10^{-3} \\
3.3 \times 10^{-3} \\
4.4 \times 10^{-3} \\
6.3 \times 10^{-4}\end{array}$ & $\begin{array}{r}M \\
11 \\
24 \\
9 \\
12 \\
11 \\
12 \\
11 \\
11 \\
8 \\
8 \\
5 \\
4 \\
10 \\
23 \\
24\end{array}$ & $\begin{array}{c}1.4 \times 10^{-4} \\
2.8 \times 10^{-3} \\
3.5 \times 10^{-3} \\
1.6 \times 10^{-3} \\
7.9 \times 10^{-3} \\
7.4 \times 10^{-3} \\
4.6 \times 10^{-3} \\
3.1 \times 10^{-3} \\
3.3 \times 10^{-3} \\
3.3 \times 10^{-3} \\
2.8 \times 10^{-3} \\
1.4 \times 10^{-3} \\
4.2 \times 10^{-3} \\
1.7 \times 10^{-3} \\
\times 10 \\
4.6 \times 10^{-4}\end{array}$ & $\begin{array}{r}\mathrm{NA} \\
4 \\
16 \\
4 \\
13 \\
7 \\
12 \\
11 \\
13 \\
11 \\
7 \\
7 \\
1 \\
4 \\
0 \\
19\end{array}$ & $\begin{array}{c}1.7 \times 10^{-4} \\
3.4 \times 10^{-3} \\
4.8 \times 10^{-3} \\
3.0 \times 10^{-3} \\
8.4 \times 10^{-3} \\
7.7 \times 10^{-3} \\
3.7 \times 10^{-3} \\
3.5 \times 10^{-3} \\
3.6 \times 10^{-3} \\
2.5 \times 10^{-3} \\
3.0 \times 10^{-3} \\
1.6 \times 10^{-3} \\
4.3 \times 10^{-3} \\
2.8 \times 10^{-3} \\
\times 10 \\
5.5 \times 10^{-4}\end{array}$ & $\begin{array}{l}\mathrm{M} \\
15 \\
40 \\
13 \\
25 \\
18 \\
24 \\
22 \\
24 \\
19 \\
15 \\
12 \\
13 \\
14 \\
M \\
43\end{array}$ & $\begin{array}{r}1 \\
304 \\
639 \\
1370 \\
2100 \\
2466 \\
3561 \\
3927 \\
4292 \\
4657 \\
5022 \\
5388 \\
5753 \\
6118 \\
7579 \\
8097\end{array}$ \\
\hline${ }^{137} \mathrm{Cs}$ & $\begin{array}{l}1.4 \times 10^{-2} \\
8.7 \times 10^{-1} \\
7.9 \times 10^{-1} \\
9.5 \times 10^{-1} \\
9.4 \times 10^{-1} \\
4.8 \times 10^{-1} \\
3.0 \times 10^{-1} \\
1.8 \times 10^{-1}\end{array}$ & $\begin{array}{l}M \\
M \\
47 \\
37 \\
44 \\
22 \\
30 \\
19\end{array}$ & $\begin{array}{l}8.4 \times 10^{-3} \\
5.2 \times 10^{-1} \\
4.1 \times 10^{-1} \\
4.7 \times 10^{-1} \\
4.9 \times 10^{-1} \\
3.0 \times 10^{-1} \\
1.9 \times 10^{-1} \\
1.5 \times 10^{-1}\end{array}$ & $\begin{array}{l}M \\
M \\
49 \\
37 \\
45 \\
24 \\
21 \\
18\end{array}$ & $\begin{array}{l}1.1 \times 10^{-2} \\
6.8 \times 10^{-1} \\
5.7 \times 10^{-1} \\
6.7 \times 10^{-1} \\
6.8 \times 10^{-1} \\
3.9 \times 10^{-1} \\
2.5 \times 10^{-1} \\
1.7 \times 10^{-1}\end{array}$ & $\begin{array}{l}M \\
\mathbf{M} \\
96 \\
74 \\
89 \\
46 \\
51 \\
37\end{array}$ & $\begin{array}{r}1 \\
304 \\
639 \\
1370 \\
2831 \\
6118 \\
7213 \\
0097\end{array}$ \\
\hline
\end{tabular}

MS = Not available 
Table 2

Utirix Body Durdens

\begin{tabular}{|c|c|c|c|c|c|c|c|}
\hline & \multicolumn{2}{|c|}{ Adult Males } & \multicolumn{2}{|c|}{ Adult resies. } & \multicolumn{2}{|c|}{ Adult: } & \multirow[b]{2}{*}{$\begin{array}{l}\text { Deys Pout } \\
\text { neturn } \\
\text { Dore }\end{array}$} \\
\hline & $\begin{array}{l}\text { Body } \\
\text { Burden } \\
\mu C i \\
\end{array}$ & $\begin{array}{l}\text { Sumber } \\
\text { of } \\
\text { Perion: }\end{array}$ & $\begin{array}{l}\text { Body } \\
\text { burden } \\
\mu \mathrm{Ci} \\
\end{array}$ & $\begin{array}{l}\text { Number } \\
\text { of } \\
\text { Persons }\end{array}$ & $\begin{array}{l}\text { Dody } \\
\text { Durden } \\
\text { HCi }\end{array}$ & $\begin{array}{l}\text { Muser } \\
\text { of } \\
\text { Pereon }\end{array}$ & \\
\hline $\begin{array}{l}60 \mathrm{Co} \\
\mathrm{D} \\
\mathrm{D}\end{array}$ & $\begin{array}{l}4.0 \times 10^{-3} \\
9.7 \times 10^{-4}\end{array}$ & & $\begin{array}{l}3.1 \times 10^{-3} \\
7.6 \times 10^{-4}\end{array}$ & & $\begin{array}{l}3.5 \times 10^{-3} \\
8.7 \times 10^{-4}\end{array}$ & & $\begin{array}{l}2464 \\
3924\end{array}$ \\
\hline${ }^{65} \mathrm{Zn}$ & $\begin{array}{l}3.5 \times 10^{-1} \\
2.7 \times 10^{-1} \\
3.7 \times 10^{-2}\end{array}$ & $\begin{array}{r}2 \\
14\end{array}$ & $\begin{array}{c}- \\
1.6 \times 10^{-1} \\
3.3 \times 10^{-2}\end{array}$ & 15 & $\begin{array}{c}- \\
2.1 \times 10^{-1} \\
3.5 \times 10^{-2}\end{array}$ & 29 & $\begin{array}{l}1734 \\
2464\end{array}$ \\
\hline${ }_{0}^{55} \mathrm{Fe}$ & $1.7 \times 10^{-1}$ & & $1.6 \times 10^{-1}$ & & $1.6 \times 10^{-1}$ & & 6114 \\
\hline${ }^{90} \mathrm{Sr}$ & $\begin{array}{c}1.4 \times 10^{-3} \\
1.2 \times 10^{-3} \\
\mathrm{~N} \\
1.5 \times 10^{-4}\end{array}$ & $\begin{array}{r}5 \\
5 \\
12 \\
14\end{array}$ & $\begin{array}{c}2.4 \times 10^{-3} \\
1.3 \times 10^{-3} \\
\times 4 \\
1.5 \times 10^{-4}\end{array}$ & $\begin{array}{r}2 \\
6 \\
12 \\
17\end{array}$ & $\begin{array}{c}1.7 \times 10^{-3} \\
1.3 \times 10^{-3} \\
M \\
1.5 \times 10^{-4}\end{array}$ & $\begin{array}{l}7 \\
11 \\
24 \\
31\end{array}$ & $\begin{array}{l}1734 \\
7213 \\
8659 \\
9225\end{array}$ \\
\hline${ }^{137} \mathrm{Cs}$ & $\begin{array}{l}4.1 \times 10^{-1} \\
2.9 \times 10^{-1} \\
2.6 \times 10^{-1} \\
1.2 \times 10^{-1} \\
6.2 \times 10^{-2}\end{array}$ & $\begin{array}{r}\mathrm{M} \\
15 \\
9 \\
27 \\
19\end{array}$ & $\begin{array}{l}2.7 \times 10^{-1} \\
2.0 \times 10^{-1} \\
1.3 \times 10^{-1} \\
7.8 \times 10^{-2} \\
4.3 \times 10^{-2}\end{array}$ & $\begin{array}{l}M \\
15 \\
13 \\
21 \\
17\end{array}$ & $\begin{array}{l}3.3 \times 10^{-1} \\
2.5 \times 10^{-1} \\
1.3 \times 10^{-1} \\
1.0 \times 10^{-1} \\
5.3 \times 10^{-2}\end{array}$ & $\begin{array}{l}M 4 \\
30 \\
22 \\
48 \\
36\end{array}$ & $\begin{array}{l}1004 \\
1734 \\
7213 \\
8309 \\
9225\end{array}$ \\
\hline
\end{tabular}

D = Ratio derived body burden

NA = Not available

* - Measured at Argonne Mationa! Laboratory 


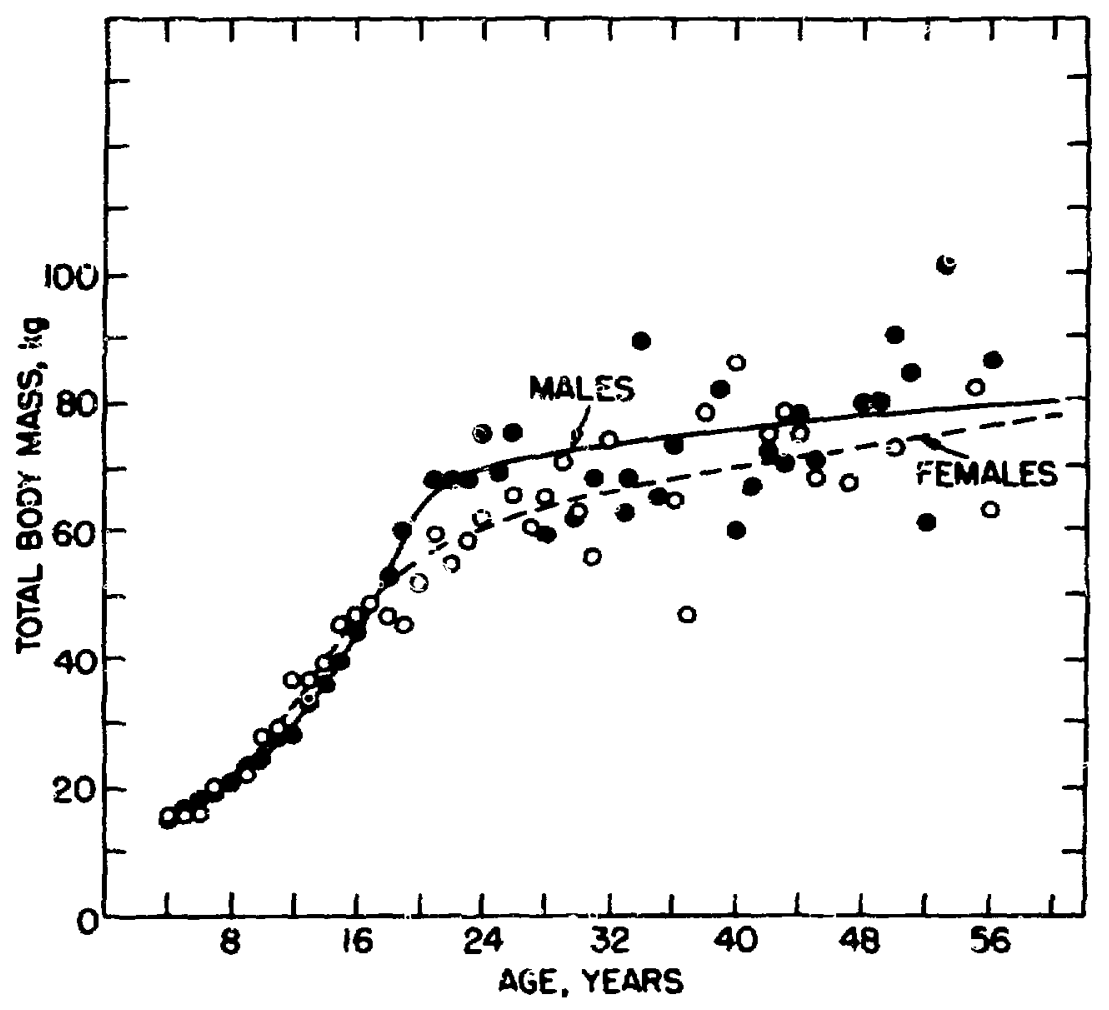

Fig. 1 Bouy Hass as a Function of Age for Residents of Rongelap Atol1 
BRAVo test. These data, together with appropriate conversion factors and living pattern models, provided an estimate of external dose equivalent.

\section{METHODS}

Exponentially declining activity concentrations have been observed in surface soil for ${ }^{137} \mathrm{Cs},{ }^{129} \mathrm{I}$, and ${ }^{90} \mathrm{Sr}$ from 1954 to the present on Rongelap and Utirik Atolls. Declining activity concentrations have also been observed in vegetation at a rate greater than that predicted by radioactive decay. Thus exponential decline in dietary activity was assumed and the following general equations were derived.

$$
\lambda P^{0}=\frac{U U_{s} / f_{u}-q^{0}\left(\Sigma_{i} K_{i} x_{i}^{\prime} e^{-\left(\lambda+K_{i}\right) t}\right)}{f_{1}\left(\sum_{i} \frac{x_{i} K_{i}}{K_{i}-K_{E}}\left(e^{-\left(\lambda+K_{E}\right) t}-e^{-\left(\lambda+K_{i}\right) t}\right)\right)},
$$

or

$$
\lambda P^{\circ}=\frac{\left.q-q^{0} \sum_{i} x_{i}^{\prime} e^{-\left(\lambda+K_{i}\right) t}\right)}{f_{1}\left(\sum_{i} \frac{X_{i}}{K_{i}-K_{E}}\left(e^{-\left(\lambda+K_{E}\right) t}-e^{-\left(\lambda+K_{i}\right) t}\right)\right.},
$$

and

$$
\begin{aligned}
D=E_{1} \lambda P^{0} \Sigma_{i} \frac{x_{i}}{K_{i}-K_{E}} & \left(\frac{K_{i}-K_{E}-\left(\lambda+K_{i}\right) e^{-\left(\lambda+K_{E}\right) t}+\left(\lambda+K_{E}\right) e^{-\left(K_{i}+\lambda\right) t}}{\left(K_{E}+\lambda\right)\left(K_{i}+\lambda\right)}\right) \\
& +q^{0} \Sigma_{i} \frac{x_{i}^{\prime}}{\lambda+K_{i}}\left(1-e^{-\left(\lambda+K_{i}\right) t}\right),
\end{aligned}
$$

where 


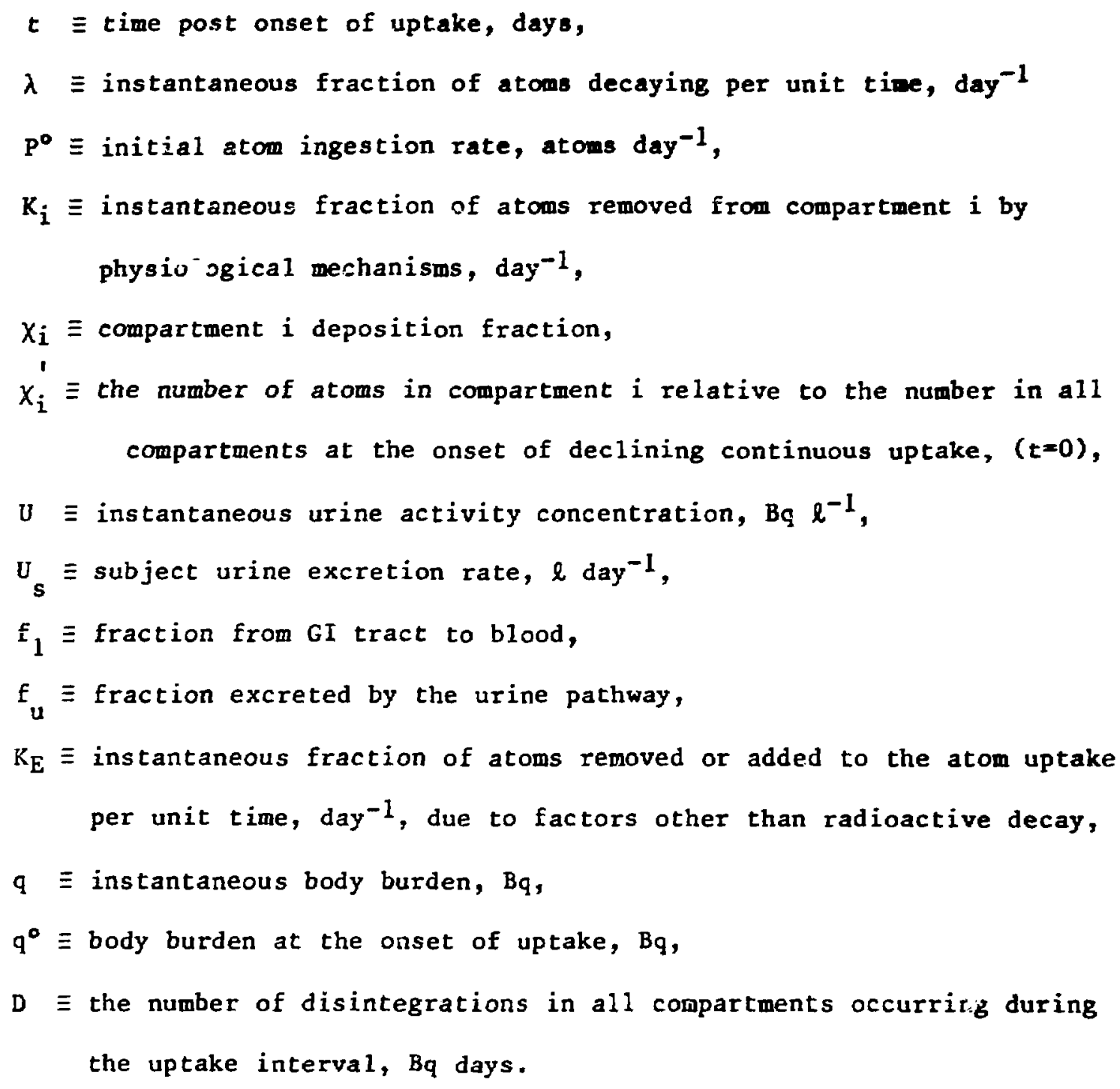

The development of Eqs. (1), (2), and (3) was based on the following convolution integral. A.t some variable time, $\tau$, defined during a fixed uptake interval, $T$, the daily activity ingestion rate crossing the gastrointestinai tract to blood is given by

$$
\lambda f_{1} P^{\circ} e^{-\left(k_{E}+\lambda\right) \tau}
$$


The whole body retention at any time $t-\tau$ of the fraction of initial radioactivity inputed at time $\tau$ is

$$
\Sigma_{i} X_{i} e^{-\left(\lambda+k_{i}\right)(t-\tau)}
$$

Thus, the instantaneous activity at time $t-\tau$ that remains following input during $\mathrm{d} \tau$ is

$$
\lambda f_{i} P^{\circ} e^{-\left(K_{E}+\lambda\right) \tau} \Sigma_{i} X_{i} e^{-\left(\lambda+K_{i}\right)(t-\tau)} d \tau
$$

It follows that the instantaneous activity at time $t-\tau$ that remains following input during $T$ is

$$
\int_{0}^{T} \lambda f_{1} P^{\circ} e^{-\left(K_{E}+\lambda\right) \tau} \Sigma_{i} X_{i} e^{-\left(\lambda+K_{i}\right)(t-\tau)} d \tau
$$

The solution of the integral yields a general expression that depends on the user defining $t$. For example, if $t$ is the fixed uptake interval, $T$, plus an additional fixed post uptake interval, $\emptyset$, then the body burden at $T+$ is given by

$$
\frac{\lambda P^{\circ} f_{1} \Sigma_{i} X_{i}\left(e^{-\left(\lambda+K_{E}\right) T}-e^{-\left(\lambda+K_{i}\right) T}\right) e^{-\left(\lambda+K_{i}\right)}}{K_{i}-K_{E}} .
$$

As previously stated, Eq. (2) applied at Rongelap and Utirik, it was for the situation that variable time $t$ was the uptake interval. Additionally, persons who returned to the atolls in June 1954 and June 1957 did so with an initial body burden, $q^{\circ}$. The behavior of this contribution to body burden, q, was embodied in the $\mathrm{q}^{\circ}$ term of Eq. (2). A similar model was used to relate 
urine activity concentration to body burden. Equation 3 was obtained by integrating Eq. (2).

Equations (1) and (2) were used to determine the instantaneous fraction of atoms removed or added to the atom uptake per unit time, $k_{E}$, and then the initial daily activity ingestion rate required to produce the measured or derived body burden. Equation (3) was used to determine the number of disintegrations that occurred in the body during the residence interval of an individual living on Rongelap or Utirik Atoll.

If the mean resijence time in the diet is much much longer than the residence interval, then constant continuous uptake is achieved. Equations (1) and (2) can be converted to the constant continuous equations by replacing $\mathrm{K}_{\mathrm{E}}$ with $-\lambda$. Single uptake expressions are obtained by setting $\mathrm{P}^{0}$ equal to zero. In some cases only radioactive decay may remove the nuclide from dietary items; for these cases $\mathrm{K}_{\mathrm{E}}$ would equal zero. In the case of the former Bikini residents. the maturing of coconut trees during residence on Bikini Atoll caused a continuously increasing dietary uptake of ${ }^{137} \mathrm{Cs}$. Thus, $\mathrm{K}_{\mathrm{E}}$ was found to have a negative value. In the case of Rongelap and Utirik, $K_{E}$ was found to have a positive value for ${ }^{137} \mathrm{Cs},{ }^{65} \mathrm{Zn},{ }^{60} \mathrm{Co}$, and ${ }^{90} \mathrm{Sr}$. This indicated that in addition to radioactive decay, some other removal mechanism decreased the radicactivity in dietary items during the residence interval. For the nuclide ${ }^{55} \mathrm{Fe}$, only one measurement was published by the BNL Medical Program (Be72); thus an estimate of $\mathrm{K}_{\mathrm{E}}$ was not possible.

$\mathrm{K}_{\mathrm{E}}$ was determined by using Eq. (1) or (2) and the population subgroup mean body burden or urine activity concentration. Portions of these bioassay data are illustrated for adult males and females in Figures 2 to 6 . Two consecutive urine or body burden data points were used to eliminate the unknown ingestion 


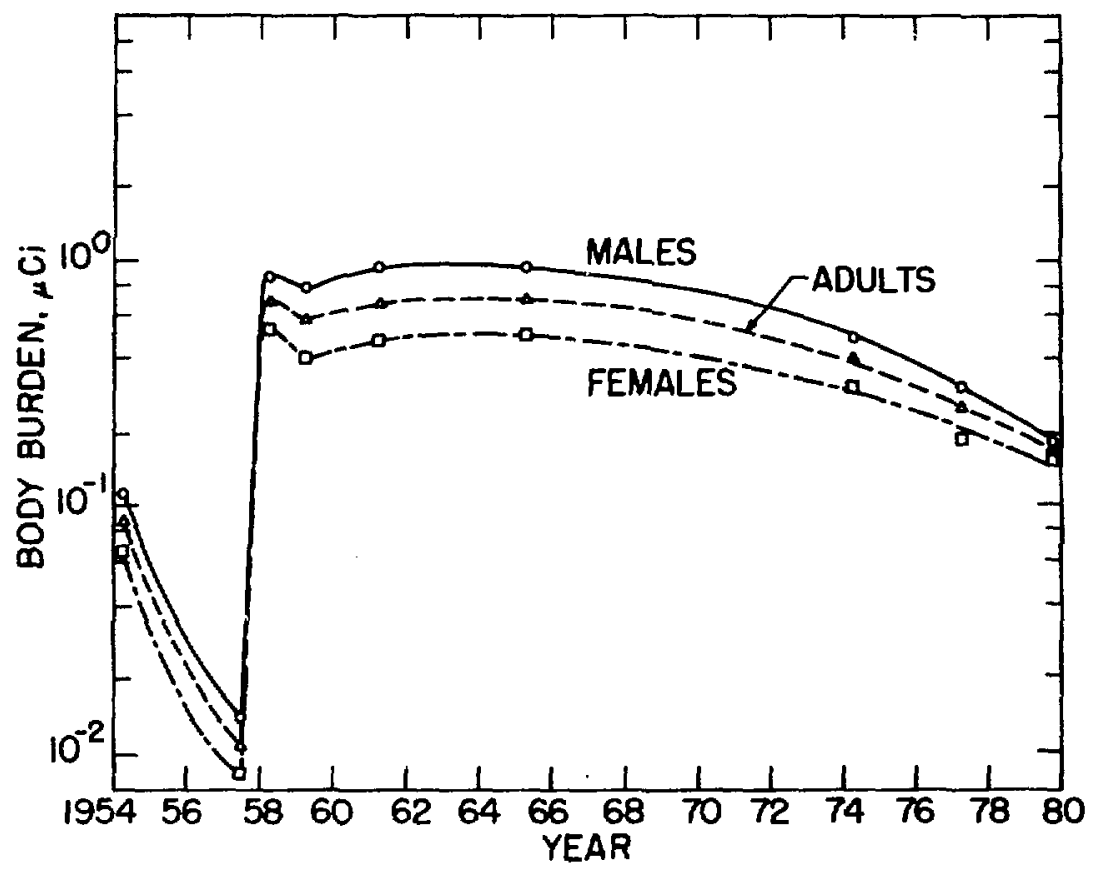

Fig. 2 Mean Adult ${ }^{137}$ Cs Body Burden History at Rongelap Ato11 


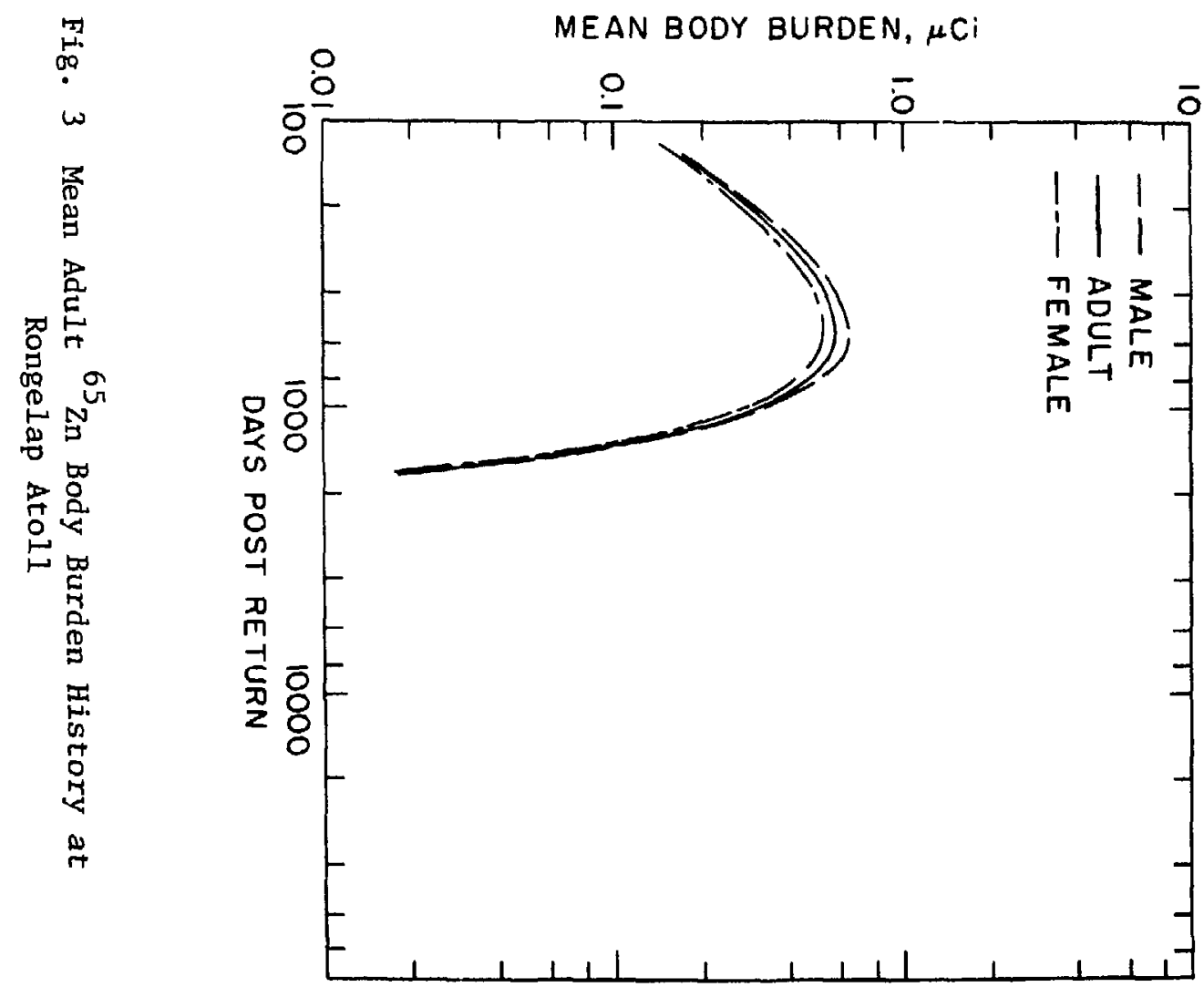




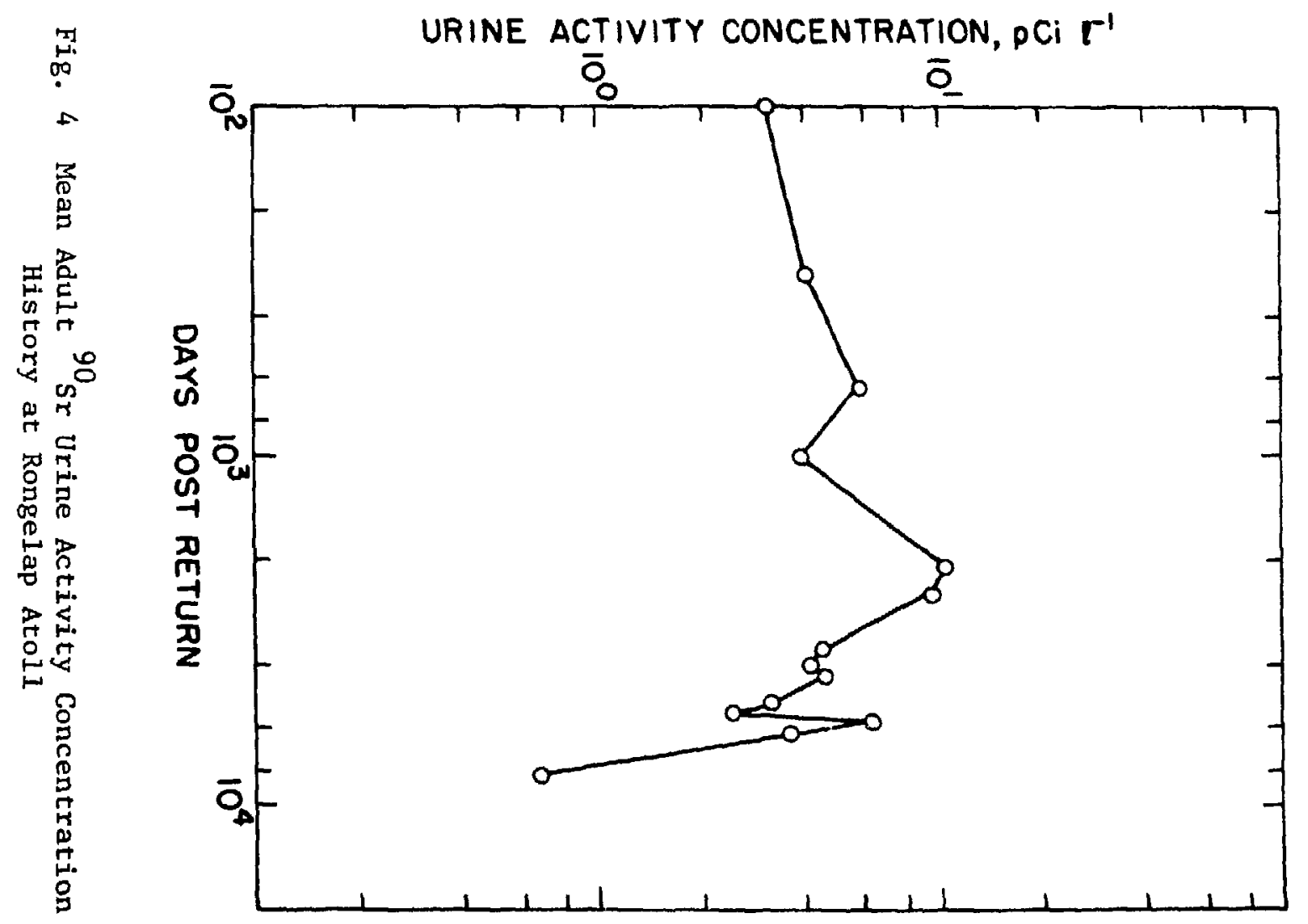




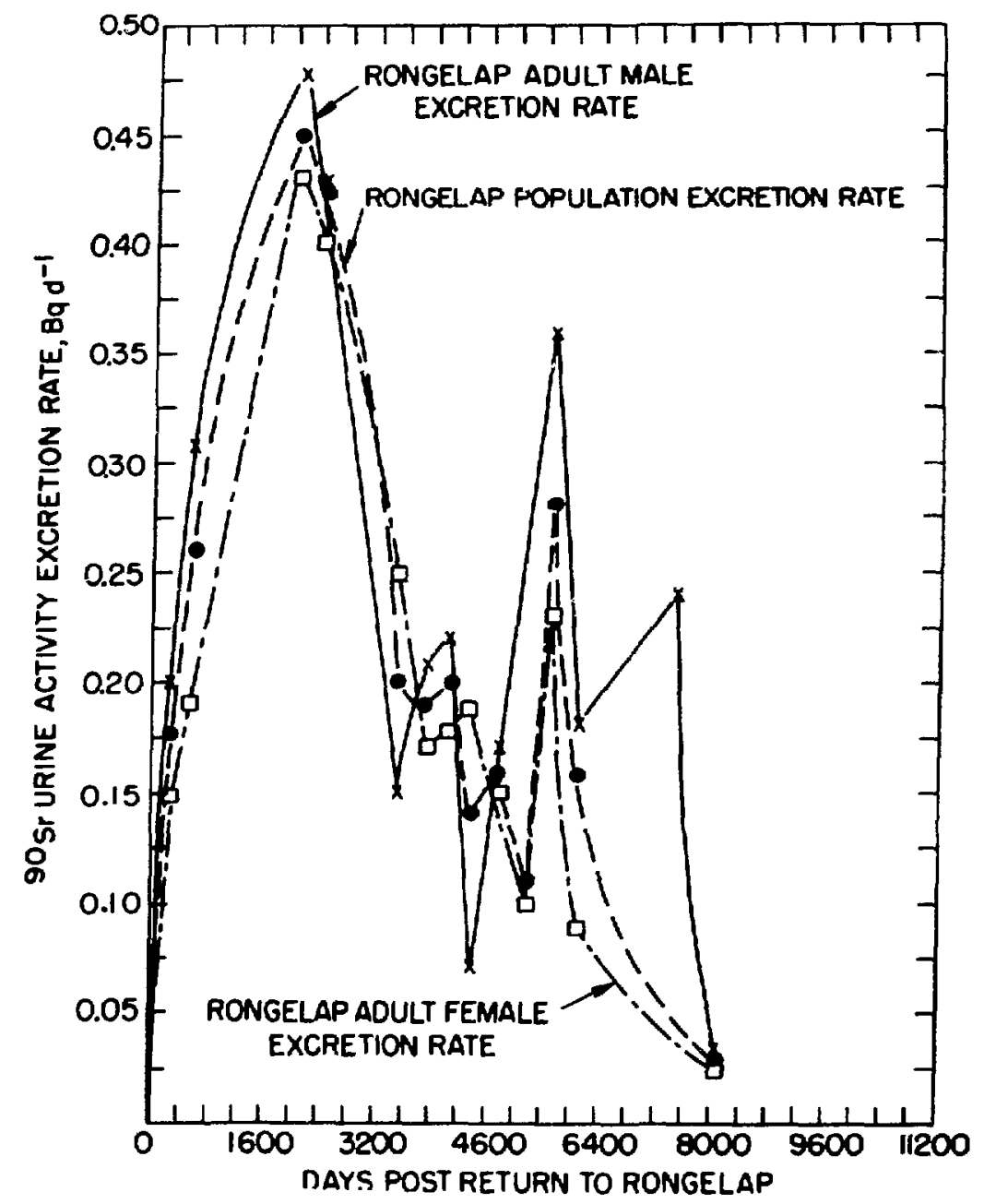

Fig. 5 Mean Adult ${ }^{90} \mathrm{Sr}$ Urine Activity Excretion Rate at Rongelap Atoll 


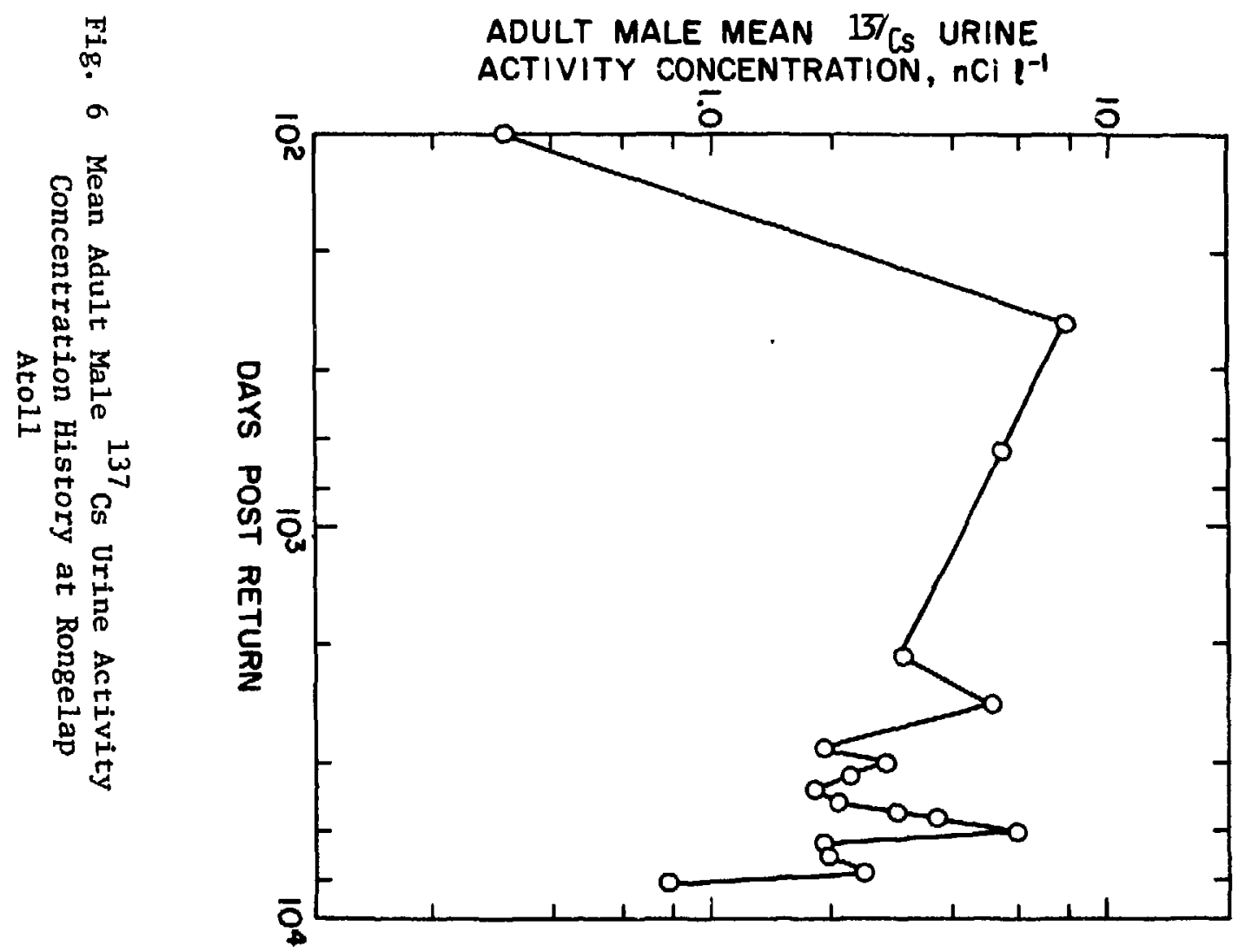


rate from the equation. This method yields $n-1$ estimates of $K_{E}$ where $n$ was the number of data points. An average value of $K_{E}$ was assigned for each nuclide, and the results for the Rongelap and Utirik populations are given in Table 3. For the evaluation of $\mathrm{K}_{\mathrm{E}}$ from Eq. 1 and 2, radiological and physiological parameters were obtained from the open 1iterature (ICRP59, ICRP68, ICRP69, ICRP79, Ki78). A representative sample of these parameters is presented in Table 4.

Table 3

Summary of Dietary Rate Constants $\left(\mathrm{K}_{\mathrm{E}^{2}} \mathrm{~d}^{-1}\right)$

\begin{tabular}{lcccc}
\hline & ${ }^{60}{ }_{\mathrm{Co}}$ & ${ }^{90} \mathrm{Sr}$ & ${ }^{65} \mathrm{Zn}$ & ${ }^{137} \mathrm{Cs}$ \\
\hline $\begin{array}{l}\text { Ronge lap Adults } \\
\text { Males }\end{array}$ & $1.5 \times 10^{-3}$ & $1.8 \times 10^{-4}$ & $3.1 \times 10^{-3}$ & $1.4 \times 10^{-4}$ \\
$\begin{array}{l}\text { Fema les } \\
\text { Adults }\end{array}$ & $1.6 \times 10^{-3}$ & $4.1 \times 10^{-4}$ & $3.5 \times 10^{-3}$ & $1.4 \times 10^{-4}$ \\
\hline $\begin{array}{l}\text { Utirik Adults } \\
\text { Males }\end{array}$ & $1.5 \times 10^{-3}$ & $1.9 \times 10^{-4}$ & $3.1 \times 10^{-3}$ & $1.4 \times 10^{-4}$ \\
Females & N.D. & $4.6 \times 10^{-4}$ & N.D. & $1.4 \times 10^{-4}$ \\
Adults & N.D. & $4.0 \times 10^{-4}$ & N.D. & $1.4 \times 10^{-4}$ \\
\hline
\end{tabular}

N.D. ENo data sufficient for analys is.

The values of $\mathrm{K}_{\mathrm{E}}$ were similar for males and females and for residents of Ronge lap and Utirik. For ${ }^{90} \mathrm{Sr}$ on Rongelap a factor of 2 difference between $K_{E}$ values was observed for males and females. The female parameter for Rongelap Atoll compares with that obtained from the Utirik data. A paired t-test of the Rongelap male and female data indicates that the male/female difference was highly probable and therefore not significant. This difference leads to a 
Iable 4

Totel Body Doainetric and Physiologic Data

\begin{tabular}{|c|c|c|c|c|c|c|c|}
\hline $\begin{array}{l}\text { Muc lide } \\
\hat{z}^{x}\end{array}$ & $\begin{array}{l}\text { Cowpartient } \\
\text { Deposition } \\
\text { Fraction } \\
x_{i}\end{array}$ & $\begin{array}{c}\text { Compertaent } \\
\text { Regoval } \\
\text { Rate Constent } \\
K_{i} \\
d^{-1}\end{array}$ & $\begin{array}{l}\text { GI Tract } \\
\text { to Blood } \\
\text { Transfer } \\
\text { E } \\
\text { f }_{1}\end{array}$ & $\begin{array}{c}\text { Fraction } \\
\text { Excreted in } \\
\text { Urine } \\
f_{u}\end{array}$ & $\begin{array}{l}\text { Decay } \\
\text { Constant } \\
\lambda \\
d^{-1}\end{array}$ & $\begin{array}{c}\text { Significant } \\
\text { Progeny } \\
\mathrm{z}^{\mathrm{x}}\end{array}$ & $\begin{array}{l}\text { Branci: ins } \\
\text { Ratio }\end{array}$ \\
\hline${ }_{55}^{137} \mathrm{Ca}$ & $\begin{array}{l}0.13 \\
0.87\end{array}$ & $\begin{array}{l}0.50 \\
0.0051\end{array}$ & 1.0 & 0.90 & $6.3 \times 10^{-5}$ & ${ }_{56}^{137 \mathrm{ma}}$ & 0.946 \\
\hline${ }_{30}^{65} \mathrm{zn}$ & $\begin{array}{l}0.25 \\
0.75\end{array}$ & $\begin{array}{l}0.058 \\
0.0022\end{array}$ & 0.35 & 0.25 & $2.8 \times 10^{-3}$ & ${ }_{29}^{65 *} \mathrm{Cu}$ & 0.49 \\
\hline${ }_{38}^{90} \mathrm{Sr}$ & $\begin{array}{l}0.89 \\
0.059 \\
0.051\end{array}$ & $\begin{array}{l}0.21 \\
7.1 \times 10^{-4} \\
1.0 \times 10^{-4}\end{array}$ & 0.20 & 0.85 & $6.5 \times 10^{-5}$ & $\begin{array}{l}90^{y} \\
39^{y} \\
90^{\star} \\
40^{2} \mathrm{r}\end{array}$ & $\begin{array}{l}1.0 \\
0.0002\end{array}$ \\
\hline${ }_{27}^{60} \mathrm{Co}$ & $\begin{array}{l}0.5 \\
0.3 \\
0.1 \\
0.1\end{array}$ & $\begin{array}{l}1.4 \\
0.12 \\
0.012 \\
8.7 \times 10^{-4}\end{array}$ & 0.05 & 0.70 & $3.6 \times 10^{-4}$ & $\begin{array}{l}60^{\star} \\
28 i\end{array}$ & 1.0 \\
\hline${ }_{26}^{55} \mathrm{Fe}$ & 1.0 & $3.5 \times 10^{-4}$ & 0.1 & 0.0 & $7.0 \times 10^{-3}$ & & \\
\hline
\end{tabular}


biüdal activity ingestion rate distribution for ${ }^{90} \mathrm{Sr}$ in the Rongelap population.

Data for ${ }^{60} \mathrm{Co}$ and ${ }^{65} \mathrm{Zn}$ were not sufficient for analysis for the Utirik Ato 11 residents. Values for $K_{E}$ observed at Rongelap were assigned to Utirik males and females and body burden histories for population subgroups were reconstructed using Eq. 1 or 2. Figures 7 and 8 illustrate the derived mean adult body burdens for all significant nuclides studied on Rongelap and Utirik. This method provides a best fit of the data shown in Figures 2 through 6 , and provides a body burden history during the early years post return at Utirik, a time when body burden measurements were not made. Actual data points are also plotted to demonstrate the fit.

The curves shown for ${ }^{55} \mathrm{Fe}$ in Figures 7 ano 8 were obtained by setting $\mathrm{K}_{\mathrm{E}}$ equal to zero. This underestimated the initial body bardens and overestimated future ones. Since ${ }^{55} \mathrm{Fe}$ contributed iess than $1.0 \%$ to the total dose equivalent, an arbitrary assignment of $K_{E}$ based on observed values for the other nuclides was not attempted. During 1974, another series of blood samples was obtained from Rongelap and Utirik (Co75). Analysis for ${ }^{55} \mathrm{Fe}$ has yet to be reported. A recalculation of ${ }^{55} \mathrm{Fe}$ body burden and its impact on early dose equivalent rates will be conducted when the data is made available. A substantial change in dose equivalent is nuc to be expected.

Figure 4 and Figure 6 illustrate the observed adilt histories of ${ }^{90} \mathrm{Sr}$ and ${ }^{137}$ Cs mean urine activity concentrations. Mean values for adult males or all adults were plotted. Measured values for ${ }^{137} \mathrm{Cs}$ body burdens were also shown in Figure 7. A much smoother curve was plotted in Figure 7 and it was determined that the collection and analysis technique for urine samples introduced the additional variations. On the basis of this observation for ${ }^{137} \mathrm{Cs}$, a smooth body 


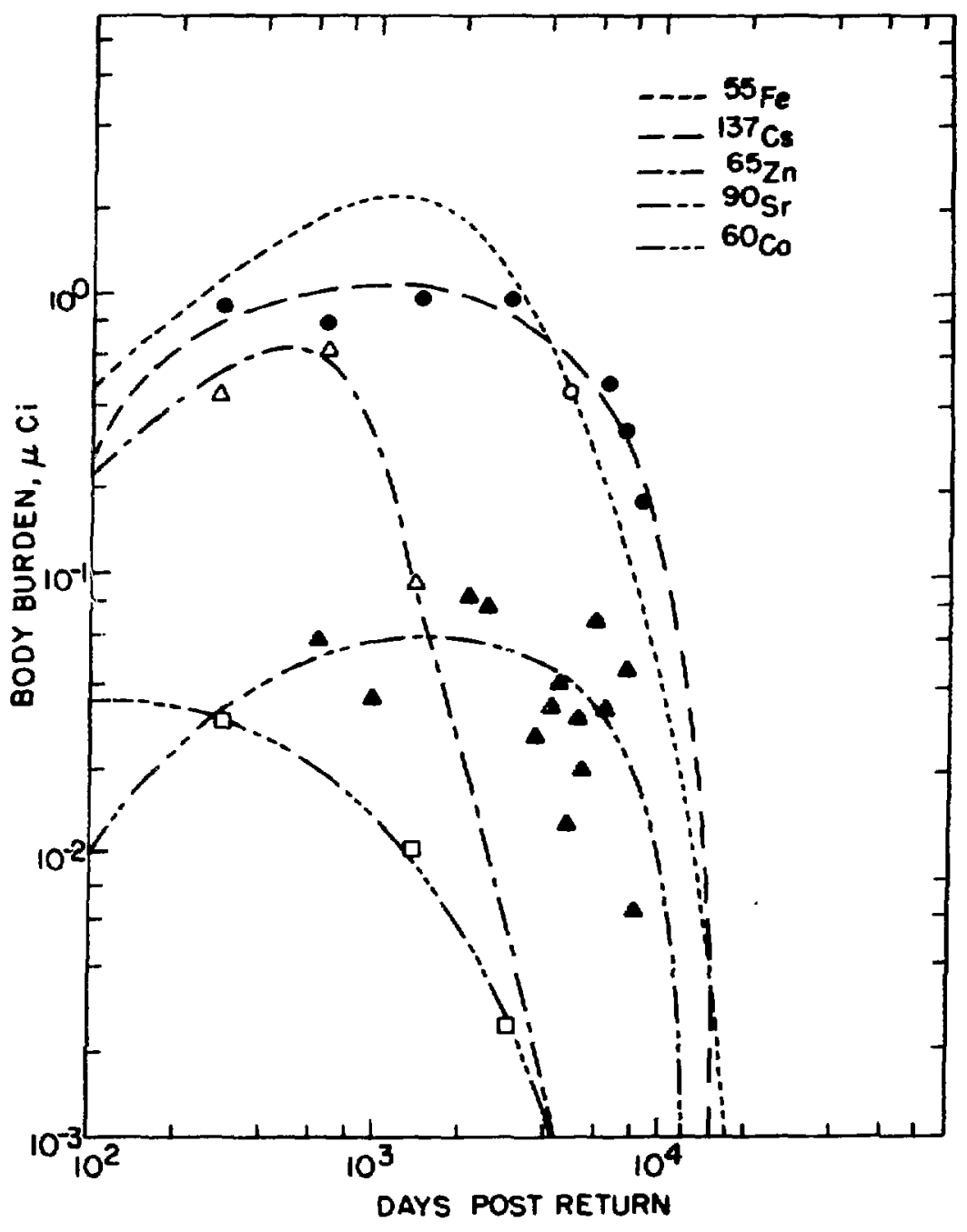

Fig. 7 Composite Nuclide Body Burden History For Adults at Rongelap Atoll 


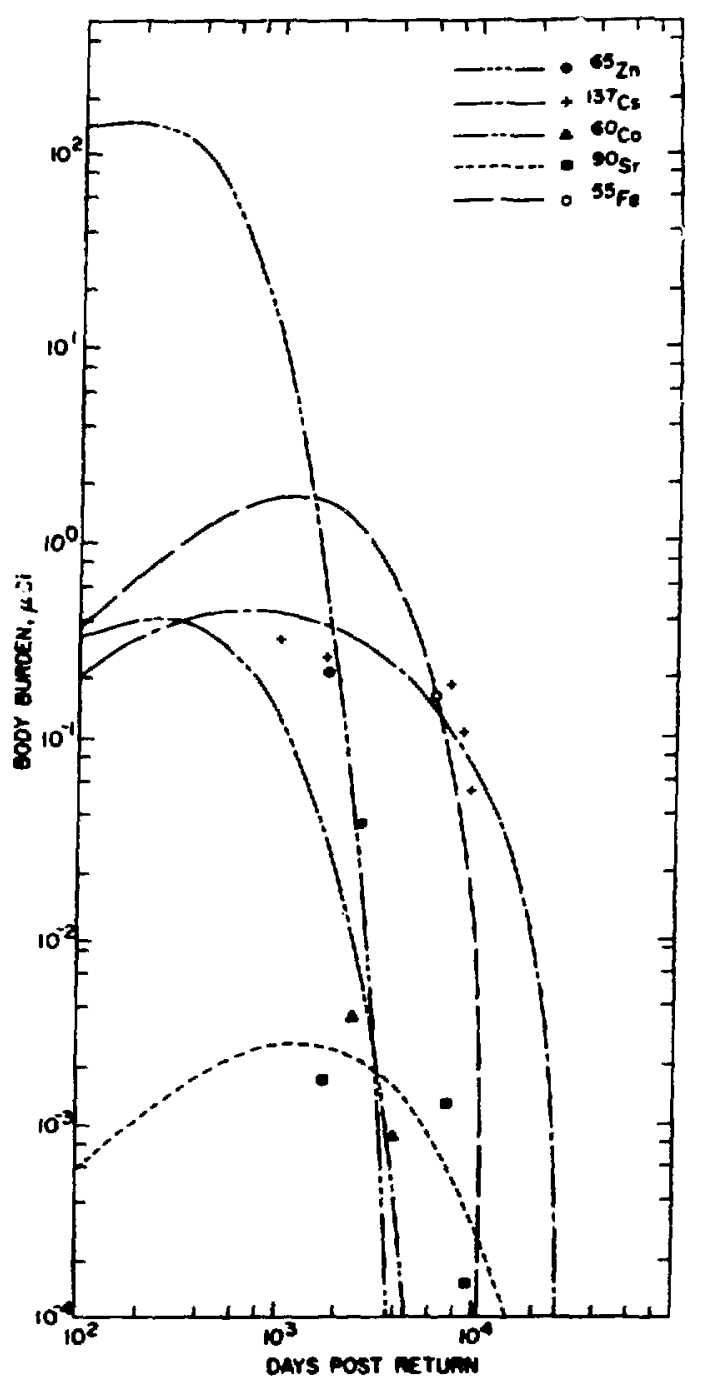

Fig. 8 Composite Nuclide Body Burden History For Adults at Utirik Atoll 
burden curve for ${ }^{90} \mathrm{Sr}$, reconstructed from raw data and Eq. 1, was considered a more accurate history. A detailed presentation of the greater variation in radiochemical analysis of urine versus direct body burden measurements can be found in Mi81.

Figure 9 illustrates the variation exhibited in the body burden of 5 randomly chosen subjects over the 25 year monitoring period. These individual variations may have had a dramatic impact on the mean data. In Figure 2, which illustrates the adult male, adult female, and adult population mean ${ }^{137} \mathrm{Cs}$ body burden for the 25 year exposure period, a decrease followed by an increase was seen during the years 1958 through 1963. Although the Castle BRAVO test initially contaminated Rongelap in March 1954, it had been proposed that the Hardtack Phase I series added to this an amount of contamination equal to that responsible for the Figure 2 body burden pattern (Co63). Figure 9 suggests that most individuals counted in those years had body burdens which remained the save or declined; however, one individual's burden ( $\$ 881 M$ ) rose and fell quite differently from the others. Several factors could have contributed to this variation from the mean such as departure and return to the atoli, sickness, the dietary contribution of imported foods, etc. Since the mean values are based on small numbers of persons who were chosen at random, it is conceivable that individuals like $881 \mathrm{M}$ influenced the mean body burdens to a greater degree than recontamination of the inhabited atolls. The impact of the individual body burden pattern on the true mean value is moot since body burdens of all individuals were not monitored consistently throughout their residence intervals except in the few cases exhibited in Figure 9. 


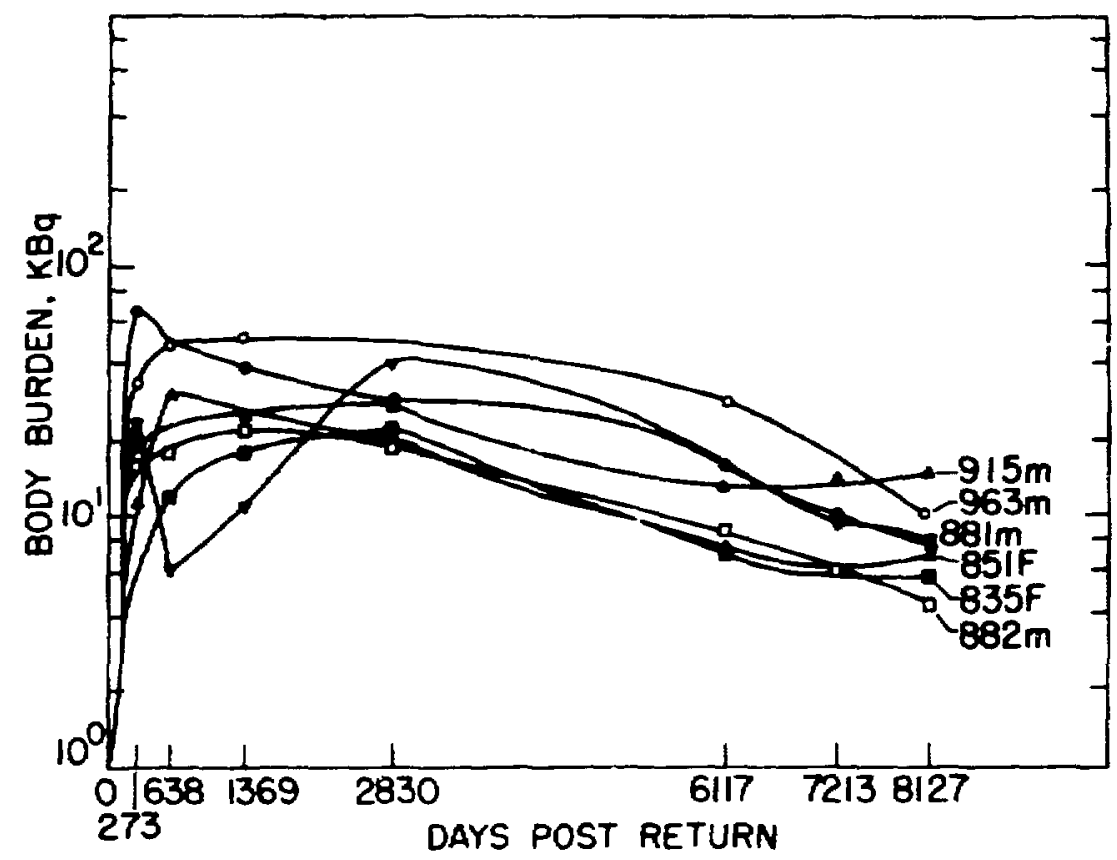

Fig 9 Individual Male and Female Body Burden Histories Randomly Chosen From The Rongelap Atoll Population 


\section{RESULTS AND DISCUSSION}

\section{Daily Activity Ingestion Rates}

Daily activity ingestion rates were calculated for dosimetrically significant nuclides post return. An exponential decline was proposed for the ingestion rate within a population subgroup and initial reference values are given in Figures 10 through 14 (June 1, 1957, was assigned as a return date to Rongelap). Figure 10 demonstrates the differences in ingestion of ${ }^{137} \mathrm{Cs}$ for various population subgroups. This undulating pattern was exhibited by ${ }^{137} \mathrm{Cs},{ }^{90} \mathrm{Sr}$, and ${ }^{65} \mathrm{Zn}$, nuclides for which sufficient data existed for analysis.

Differences in ingestion rates of the stable element at the same geographic location have been shown to occur among members of a population (ICRP 23). Age dependent diet studies for ingestion of Cs for urban Japan have values varying from $11 \mathrm{\mu g} \mathrm{d}^{-1}$ for adults to $8.6 \mathrm{\mu g} \mathrm{d}^{-1}$ for children. Sr in a western type diet rose from $600 \mu \mathrm{g} \mathrm{d}^{-1}$ for infants to $690 \mu \mathrm{g} \mathrm{d}-1$ for 5 year olds to $3,600 \mu \mathrm{g} \mathrm{d}^{-1}$ for 13 year olds and fell to a mean of $1,900 \mu \mathrm{g} \mathrm{d}^{-1}$ for adults. $\mathrm{Zn}$

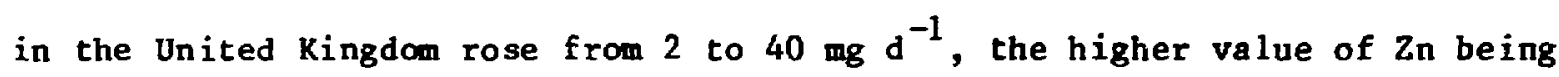
observed in adult tea drinkers. Fe ingestion in a western type diet has a minimum at age 3 and maxima at ages 1 and 20 years. Co is ingested at a rate of 20 $\mu \mathrm{g}^{-1}$ for Japanese adults and half this amount for children. The Marshallese population also exhibits dietary changes as a function of age. The authors of the Marshall Islands Diet and Living Pattern Study (Ka80) observed coconut sap being used as a major food supplement for infants, and later in adult life as a major source of daily fluid intake. Since coconuts and coconut tree sap provided the major source of ${ }^{137}$ Cs on Bikini Atoll (Le80, Mi80), the shape of Figure 10 was in agreement with the observed diet pattern. 


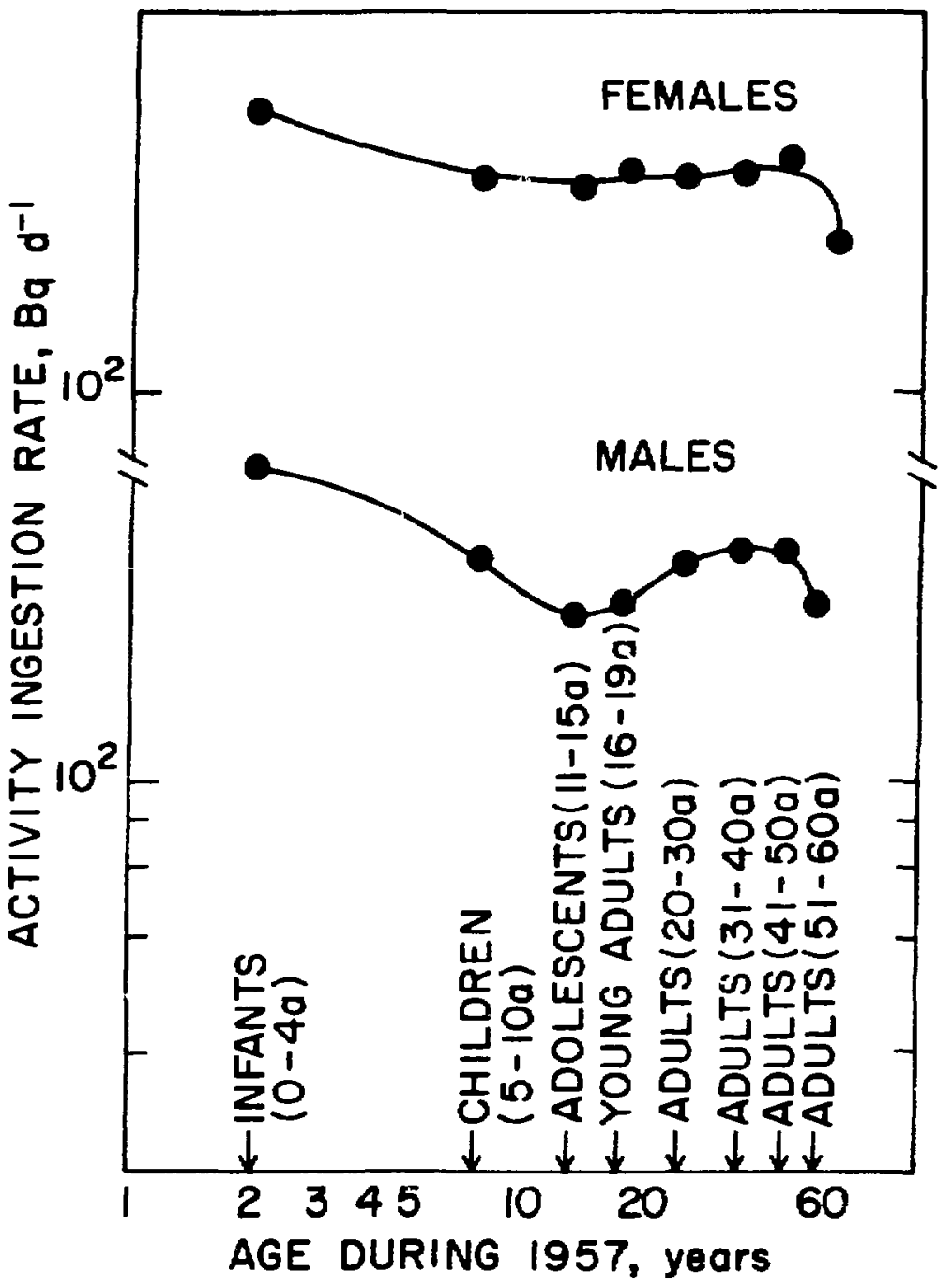

Fig. 10 Age and Sex Group Hean Values For ${ }^{137} \mathrm{Cs}$ Activity Ingestion Rate Referenced To Mid 1957 for Rongelap Atoll 

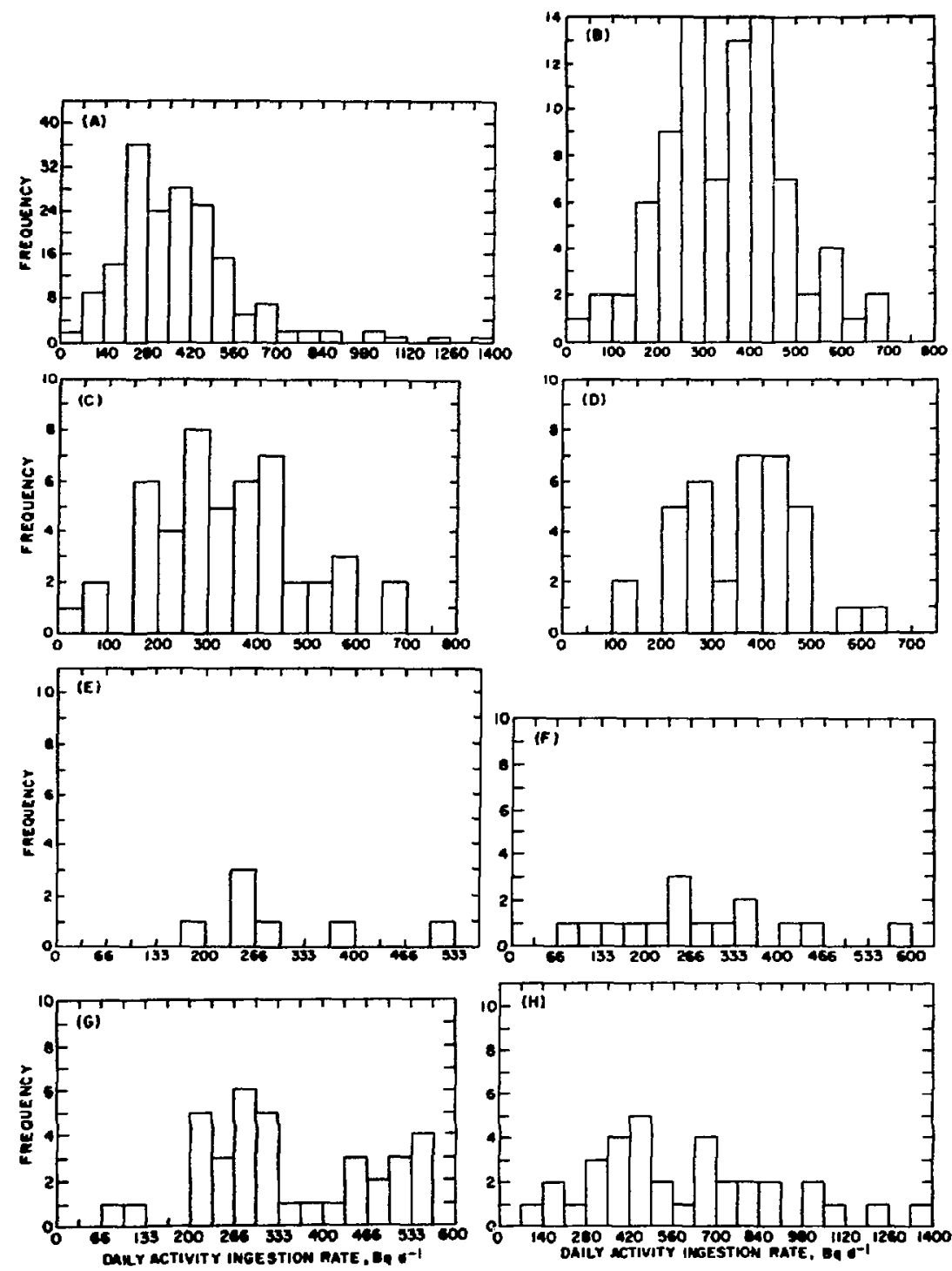

Fig. $11^{137}$ Cs Daily Activity Ingestion Rate For

(A) Al1 Residents (B) Adults (C) Adult

Males (D) Adult Females (E) Young Adults

(F) Adolescents (G) Children and (H) Infants

on Rongelap - Referenced to June 1957 


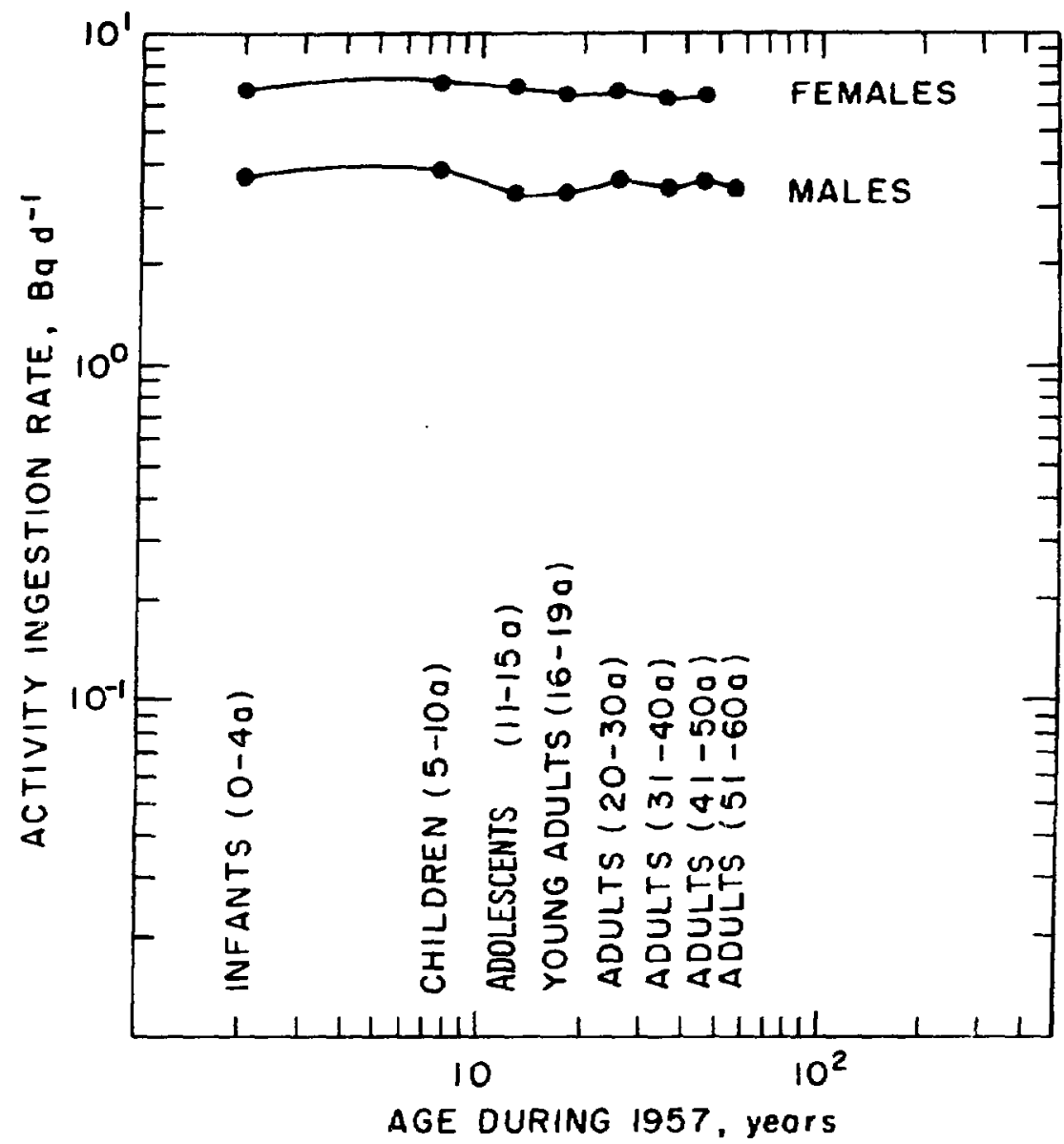

Fig. 12 Age and Sex Group Mean Values For ${ }^{90} \mathrm{Sr}$ Activity Ingestion Rate Referenced To Mid 1957 For Rongelap Atol1 

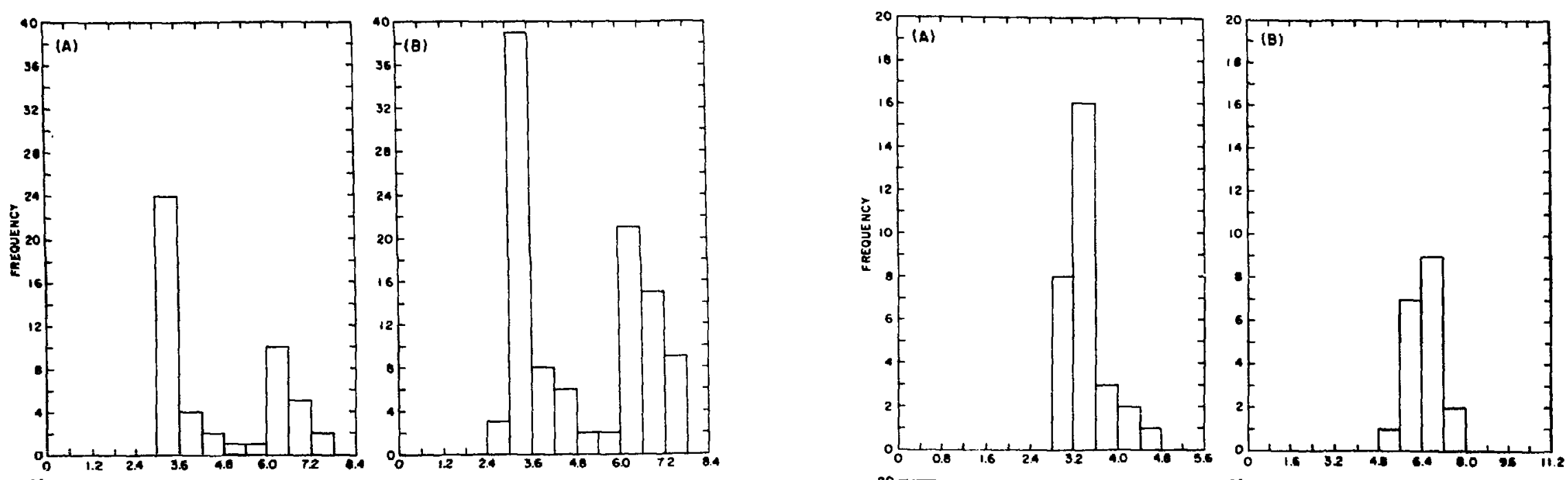

N
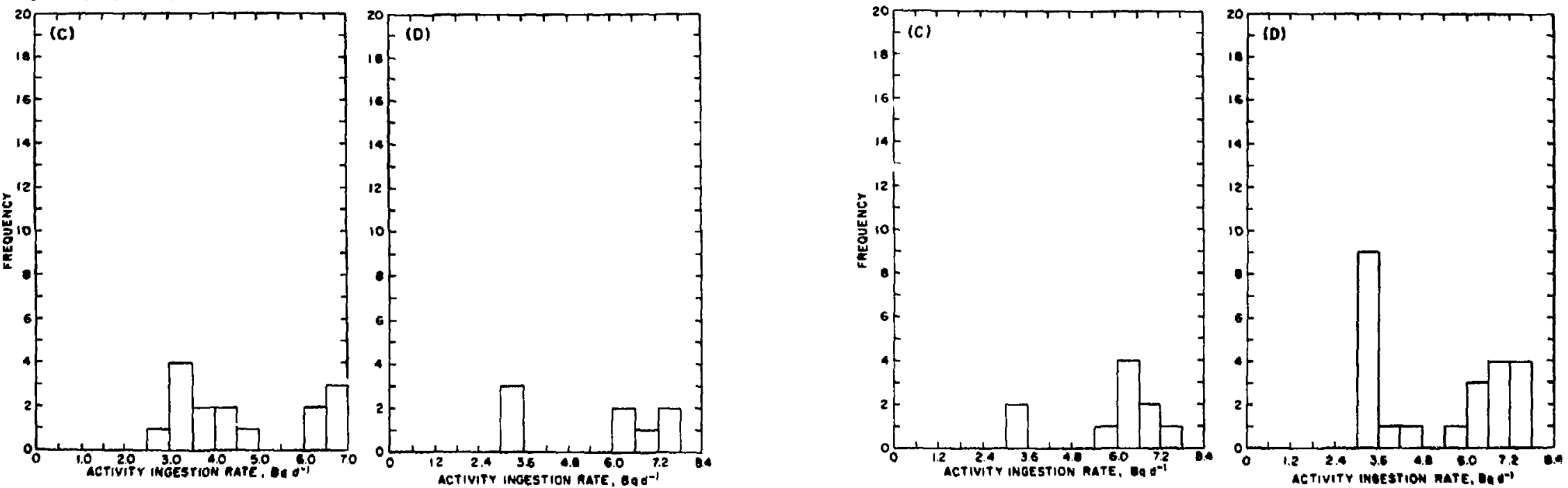

Fig. 13a ${ }^{90}$ Sr Daily Activity Ingestion Rate For (A) Adults (B) All Residents (C) Infants and (D) Adolescents on Rongelap

Fig. $13 \mathrm{~b}{ }^{90} \mathrm{Sr}$ Daily Activity Ingestion Rate for (A) Adult Males (B) Adult Females (C) Young Adults and (D) Children on Rongelap 


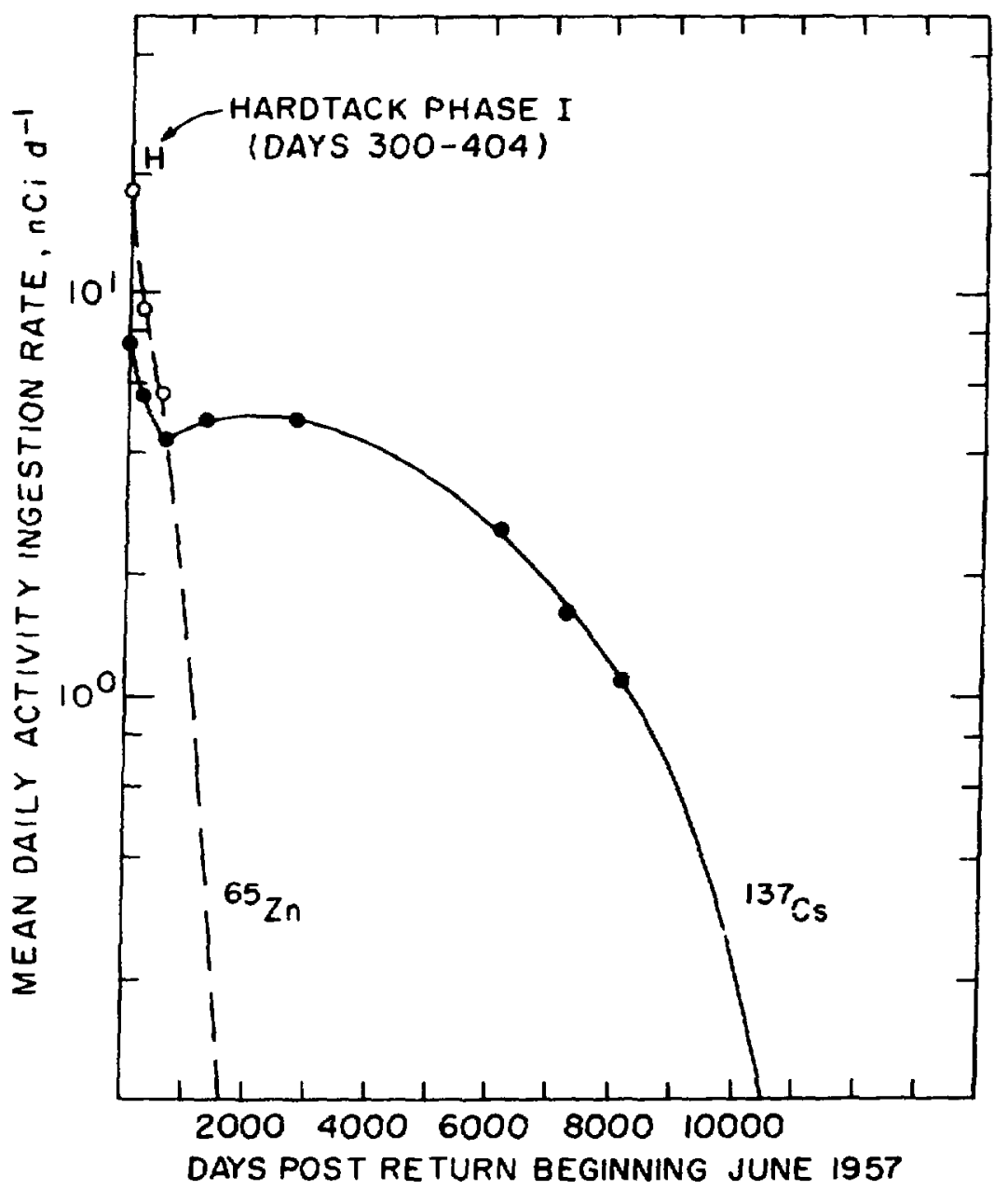

Fig. 14 Adult Meăg Daily Activity Ingestion Rate For ${ }^{13} \mathrm{Cs}$ and $65 \mathrm{Zn}$ at Rongelap Referenced to Mid-1957 
Figure 11 shows the individual data calculated for ${ }^{137} \mathrm{Cs}$ for all Rongelap residents and is referenced to June 1, 1957. The individual maximum ${ }^{137} \mathrm{Cs}$ daily activity ingestion rate was approximately 4 times the population mean value. The standard deviation observed for the adult activity ingestion rate distribution was $41 \%$ of the mean value, $39 \%$ of the mean value for young adults, $48 \%$ for adolescents, $38 \%$ for children, and $54 \%$ for infants. Adolescents and infants exhibited a broader distribution than adults, while children showed a fractional variation in activity ingestion rate similar to that of adults. Breast feeding versus coconut sap supplements would have contributed to the greater variation observed in infants. Adolescents and young adults were the population subgroups which have been observed to move frequently between atolis. This mobility would lead to greater variations in the daily activity ingestion rates relative to those observed in the more stationary population subgroups.

Figure 12 also exhibited a wave pattern; however, a distinct difference between males and females was indicated. This difference arose from the use of values for $K_{E}$ listed in Table 3 which were derived from urine data for male and female residents at Rongelap Atoll. Its major impact was on the dose equivalent rate, not on the total dose equivalent; and its effect was to cause the dose equivalent rate for males to rise and decline more rapidly than for females. Figures $13 \mathrm{a}$ and $13 \mathrm{~b}$ sumarize the individual data for ${ }^{90} \mathrm{Sr}$ for all Rongelap residents and were referenced to June 1, 1957. A bimodal shape was observed for the distributions which contained both sexes, again reflecting the difference in the ${ }^{90} \mathrm{Sr}$ dietary rate constants. Data from urine bioassay indicated that the observed difference between the male and female values for $K_{E}$ was not significant. A t-test was performed for consecutive urine measurement data during the 23 year residence interval. The results indicate that because 
of urine activity concentration variability, there was a $60 \%$ probability that the male value for $\mathrm{K}_{\mathrm{E}}$ would be different from the female value by the factor observed. Thus differences in the derived activity ingestion rates and dose equivalents were not significant.

Figure 14 shows a semi-log plot of the ${ }^{65} \mathrm{Zn}_{\mathbf{1}}$ and ${ }^{137}$ Cs activity ingestion rate histories for adults on Rongelap. A curve was drawn between points, and the appearance of an increasing ${ }^{137} \mathrm{Cs}$ ingestion rate during the 1960 's indicated the possibility of another contaminating event. The Hardtack Phase I series was conducted just prior to the observed increase in the curve and fallout from the Cactus, Yellow Wood, and Hickory experiments detonated at Bikini and Enewetak would have reached Rongelap. However, several observations fail to support the conclusion that recontamination was significant. These are as fn!lows: 1) the increase in ${ }^{137} \mathrm{Cs}$ ingestion rate was not in conjunction with an increase of ${ }^{65} \mathrm{Zn}$; however, since ${ }^{65} \mathrm{Zn}$ is an activation product it may have not been produced in the same proportions. 2) The peak ${ }^{137} \mathrm{Cs}$ body burden at Utirik occurred nearly three years after the initiating event, Castle BRAVo, while the peak body burden at Rongelap followed six years after the potentially contaminating experiments of the Hardtack series in 1958. 3) The activity ingestion rate at Utirik demonstrated a continuously declining pattern versus the humped pattern observed at Rongelap. This occurred even though there was an equal external exposure rate history following the Hardtack series as measured by the U.S. Public Health Service on both Rongelap and Utirik (Un59). 4) The peak exposure rate on Rongelap following the Hardtack series was 10,000 times less than the peak exposure rate following BRAVO. These facts suggest that the Hardtack series was not a major factor influencing the Rongelap body burden patterns. Thus it is postulated that body burden variations were caused by travel away from the atoll 
or sickness and other factors. Regardless of the cause of individual differences from the mean, a smooth description of the body burden and activity ingestion rate for the population could be adopted. On this basis a declining continuous uptake model was used.

\section{Internal Dose Equivalent Rates}

The approximate instantaneous dose equivalent rates for the total body were determined from the body burden data illustrated in Figures 7 and 8 and from the following equation

$$
\dot{H}=q I \text {, }
$$

where

$\dot{H} \equiv$ the total body dose equivalent rate, mRem $y^{-1}$,

I $\equiv$ equilibrium dose equivalent rate to the total body per unit body burden, mRem $\mathrm{y}^{-1} \mu \mathrm{Ci}^{-1}$,

$\mathrm{q} \equiv$ instanteous body burden, $\mu \mathrm{Ci}$.

The approximate nature of the estimate was due to the assumption that the radioactive atoms were distributed among the body tissues as they would be following constant continuous uptake for periods of time much greater than the mean residence $t$ ime for the total body. In the case of ${ }^{90} \mathrm{Sr}, 86 \%$ of equilibrium was assumed. These assumptions were not used in the estimate of the total dose equivalent. In addition, since mean adult body burdens were computed, a factor of 1.2 was needed to adjust for differences in body mass relative to a $70 \mathrm{kilo-}$ gram adult. Table 5 lists values of $I$ which were determined from information given in ICRP59 and corrected for body mass differences. 


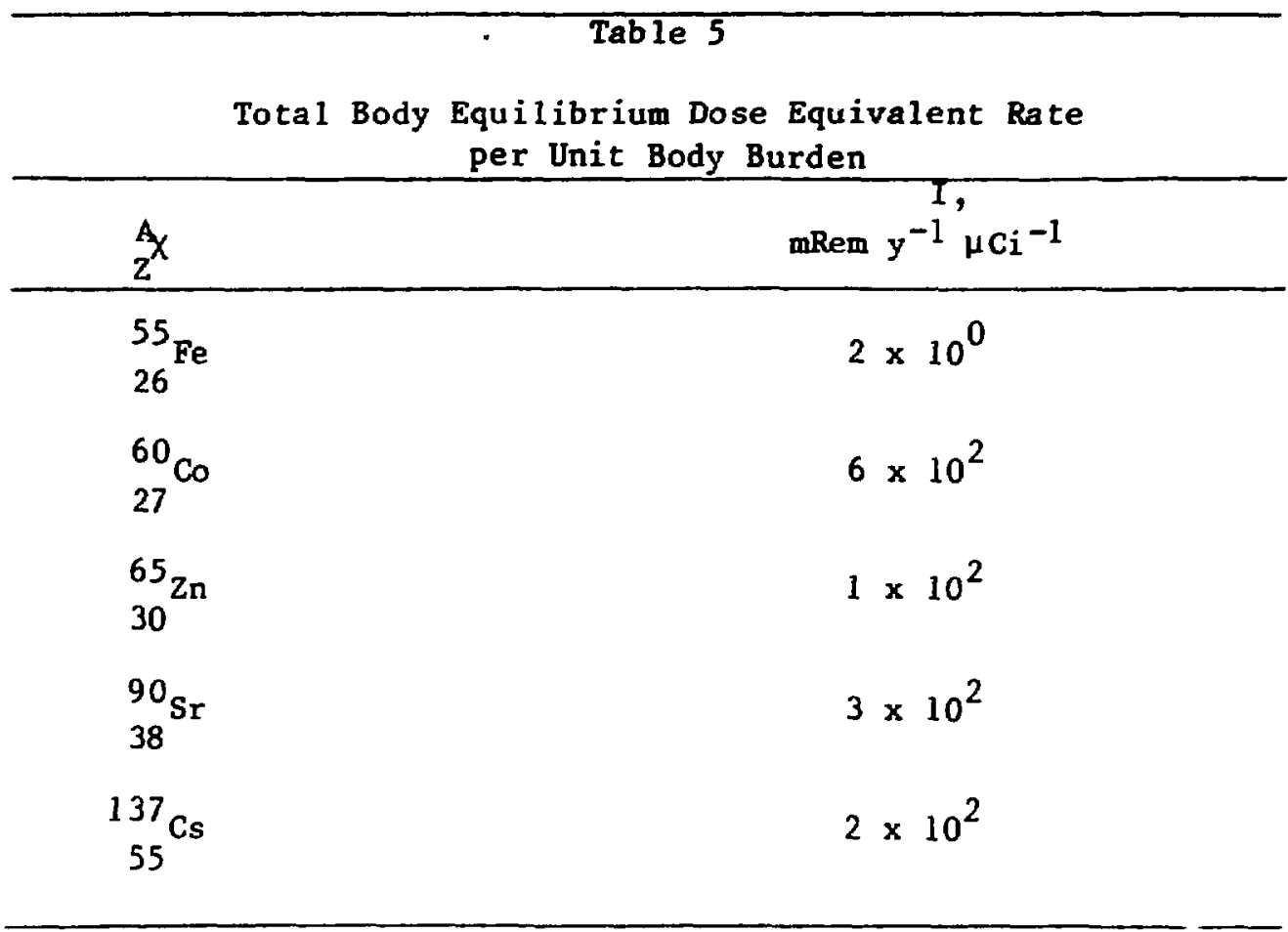

Figure 15 illustrates the relative contribution to the composite dose equivalent rate for each dosimetrically significant internally deposited nuclide. For the average Rongelap adult, the residence interval begins June 1 , 1957; however, many adults were reported to have resettled during the next 3 to 6 months (Co80b). The composite dose equivalent rate indicated that a broad maximum of approximately several hundred millirem per year pexsisted for several hundred days. Most of the dose rate is attributable to the ${ }^{137} \mathrm{Cs}$ component Cesium dominated over the entire post return period and would be of prime concern for populations returning to a contaminated enviroment years after a fission type initiating event.

Figure 16 illustrates two possibilities for the Utirik dose equivalent rate resulting from the ${ }^{65} \mathrm{Zn}$ body burden history during the first three years post-return. The higher body burden resulted from use of the two measured ${ }^{65} \mathrm{Zn}$ 


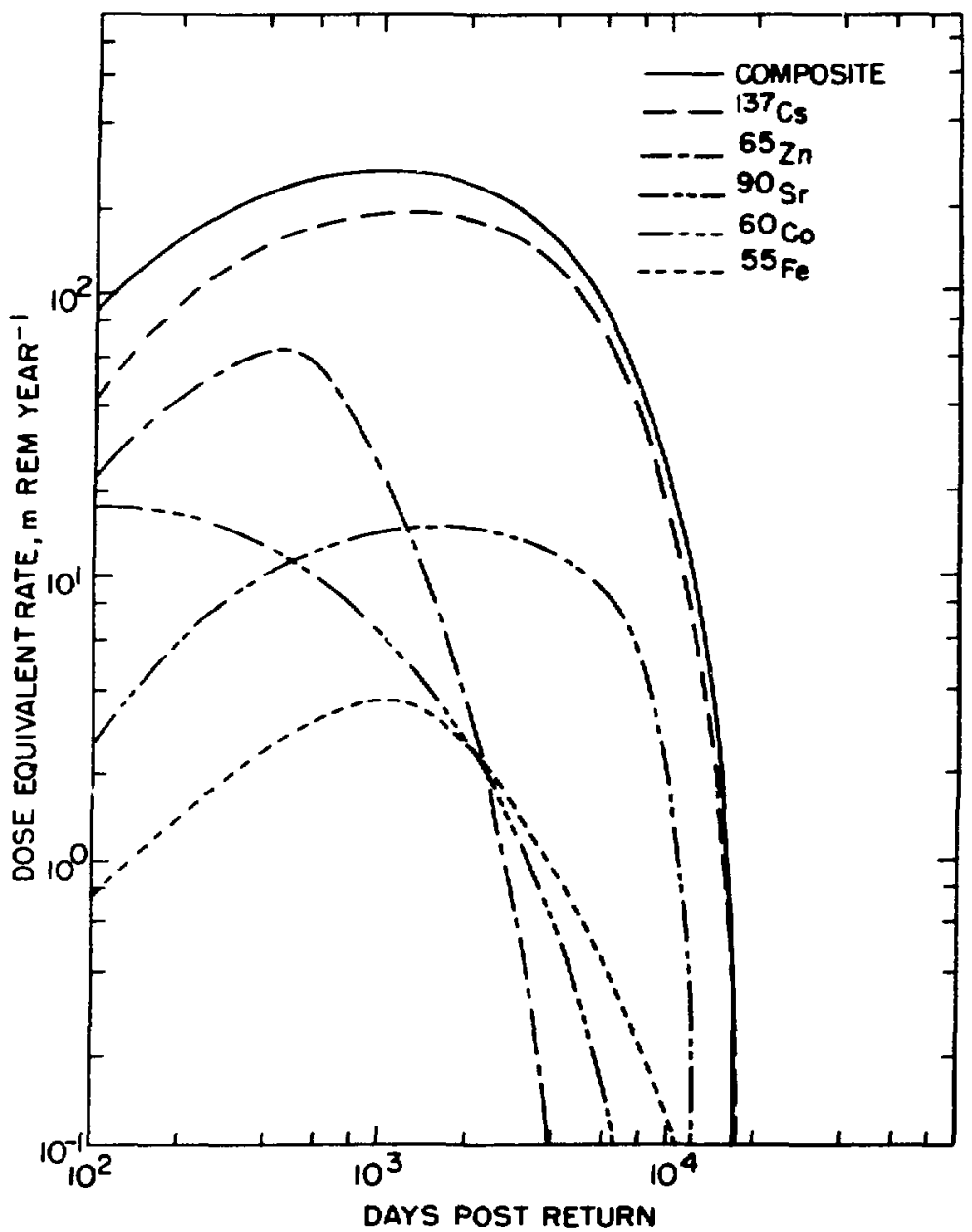

Fig. 15 Adult Mean Total Body Dose Equivalent Rate at Rongelap Atoll Post Mid 1957 


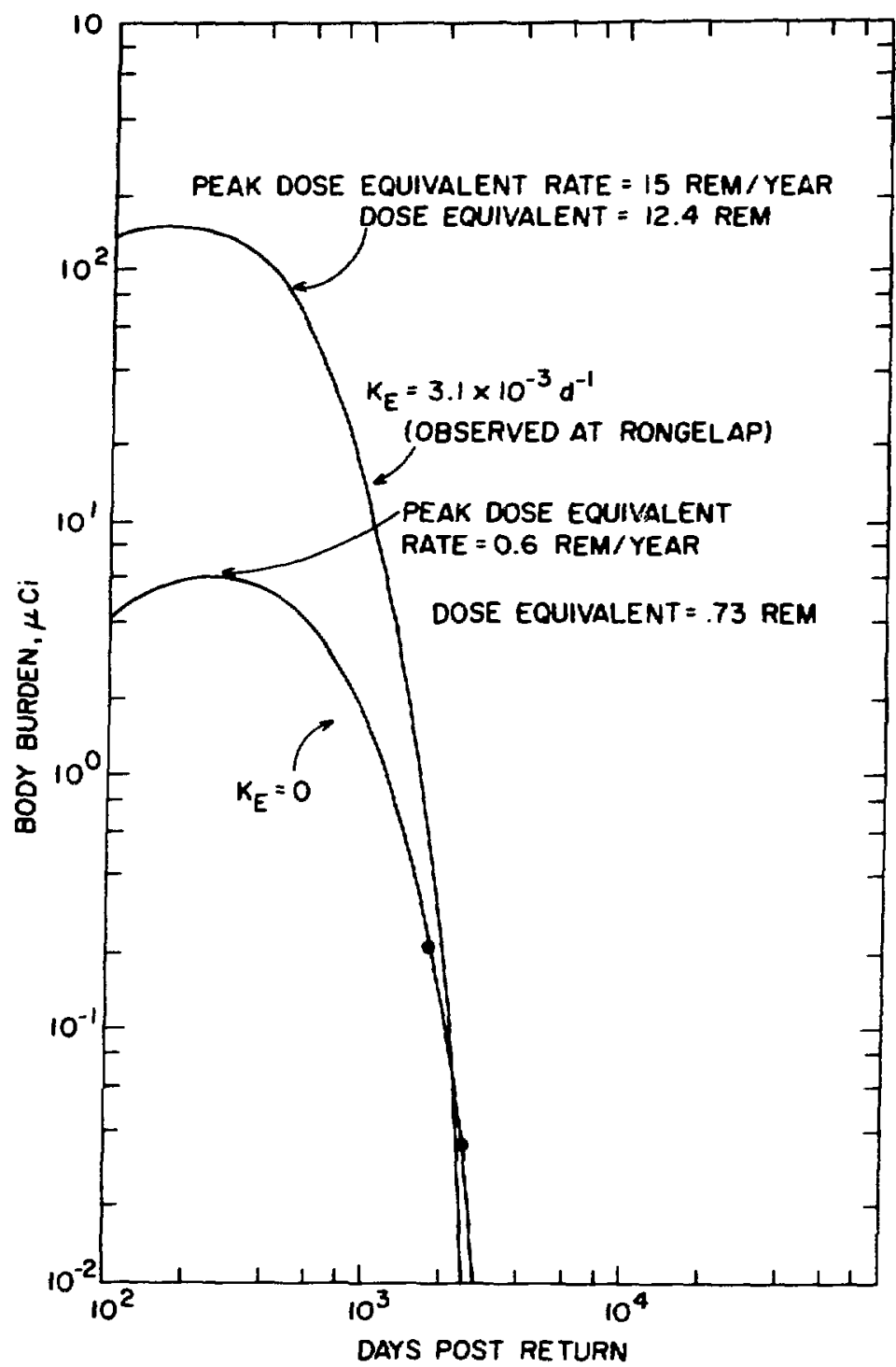

Fig. 16 Mean Adult ${ }^{65} \mathrm{Zn}$ Body Burcien, Peak Dose Equivalent Rate and Dose Equivalent For Utirik Atoll 
body burden means for adults on Utirik and the observed $K_{E}$ rate constant from Rongelap. It was observed on Rongelap that $.031 \%$ of ${ }^{65} \mathrm{Zn}$ was removed from the diet pathway each day in addition to radioactive decay. Additionally, reduction in dietary radioactivity on Rongelap had been observed for ${ }^{137} \mathrm{Cs},{ }^{90} \mathrm{Sr}$, and ${ }^{60} \mathrm{Co}$ to be greater than that predicted by radioactive decay alone. Instantaneous reduction fractions vary similar to those at Rongelap were observed at Utirik for the ${ }^{90} \mathrm{Sr}$, and ${ }^{137} \mathrm{Cs}$ nuclides. The lower curve on Figure 16 reflects the dose equivalent, dose equivalent rate, and body burden which would have occurred had radioactive decay alone accounted for the removal of ${ }^{65} \mathrm{Zn}$ from the Utirik environment. Since additional mechanisms could be measured for other nuclides at Utirik and for the ${ }^{65} \mathrm{Zn}$ nuclide on a nearby atoll, the upper curve was chosen as the most likely body burden history for adults post return to Utirik Atoll.

Figure 17 indicates the Utirik adult mean total body dose equivalent rate for each nuclide. An obvious difference relative to the Rongelap history exists; ${ }^{65} \mathrm{Zn}$ not ${ }^{137} \mathrm{Cs}$ was the major nuclide contributing to the dose equivalent rate. This was due to the Utirik population returning 3 to 4 months after the initial contaminating event, and the Rongelap population returning after 3 years. The age of the fallout had a dramatic influence on the importance of each nuclide contributing to the internal dose equivalent. In fact ${ }^{60}$ co and ${ }^{65} \mathrm{Zn}$ played major roles during the first 3 years, a time interval that corresponded to the period during which field whole body counting facilities were being developed at Brookhaven National Laboratory and when medical examinations for people on Utirik Atoll were not done. Additionally, pooled and/or individual radiochemical analysis of urine was not performed during this period. The impact of ${ }^{65} \mathrm{Zn}$ and ${ }^{60} \mathrm{Co}$ was such that even if the least conservative rate 


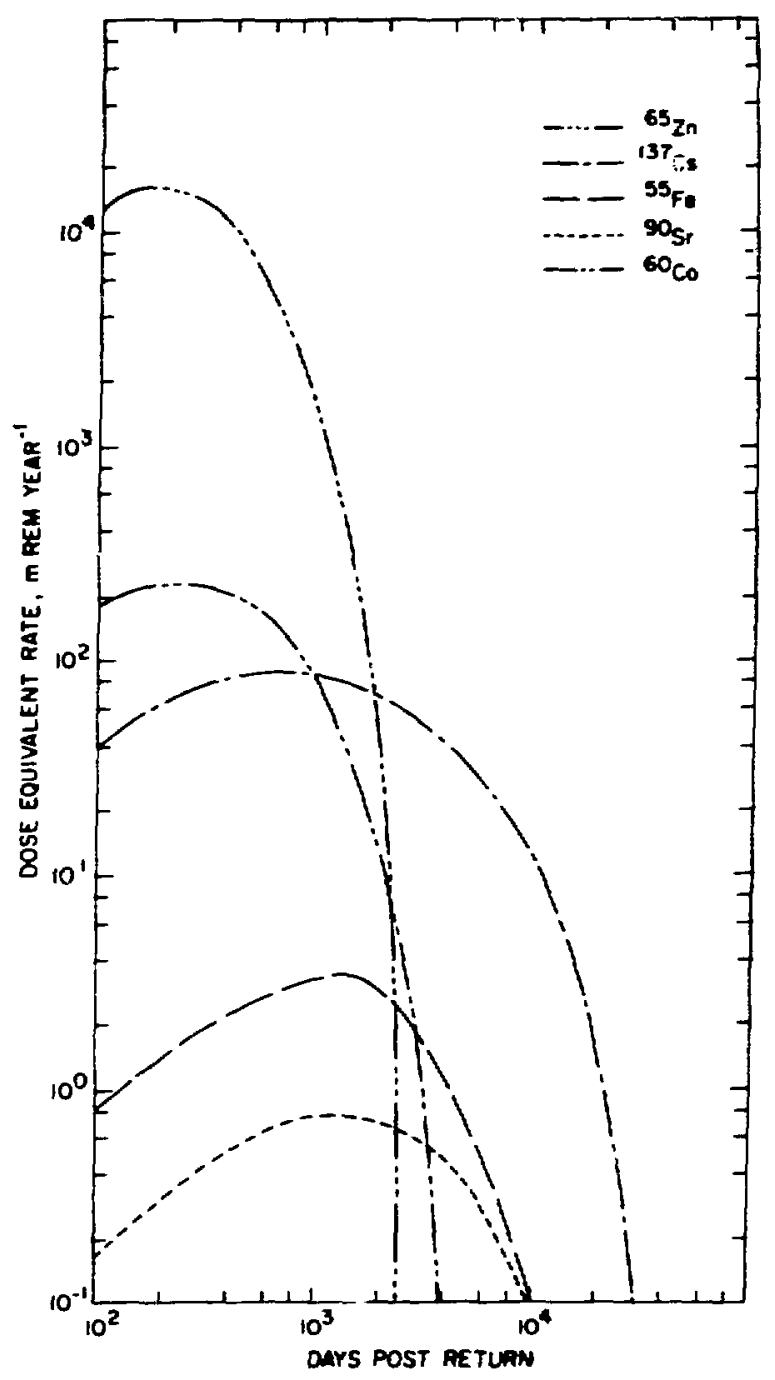

Fig. 17 Adult Mean Total Body Dose Equivalent Rate at Utirik Atoll

Post Mid 1954 
constant $\left(K_{E}=0\right)$ was used for $Z n$, the dose equivalent rate for the average adult was in excess of Federal Radiation Council Guidelines for the first 2 years following the return to Utirik.

Interna 1 Dose Equivalents

Disintegrations occurring in the total body of an individual during residence following repatriation were determined by several methods. Equation ( 3 ), together with personal body burden histories and atoll specific $K_{E}$ rate constants from Table 3, provided an initial estimate of disintegrations between consecutive body burden measurements. The second method used was a log-log plot of the subject's body burden history and an algebraic determination of area between two consecutive measured points. The third method used a linear plot of the subject's body burden history. The area under the curve was cut and weighed and compared to a standard weight of known area. Quality control procedures required that all three methods agree within $\pm 10 \%$ before a subject was assigned his or her total body disintegrations during residence post return. In generai, the methods compared to within $\pm 5 \%$.

After the total number of disintegrations occurring in a subject's body was assigned, they were apportioned among the body organs according to the following equation

$$
F=\frac{E_{2}^{\prime} \sum_{i} A_{i} B_{i}\left(\Sigma_{i} C_{i} D_{i}+\ln 2 / \lambda\right)}{\sum_{i} C_{i} D_{i}\left(\sum_{i} A_{i} B_{i}+\ln 2 / \lambda\right)},
$$

where

F $\equiv$ the fraction of total body disintegrations occurring in the organ of interest :

$A_{i} \equiv$ organ compartment deposition fraction for the element, 


$$
\begin{aligned}
& B_{i} \equiv \text { organ compartment biological half time for the element, } \\
& C_{i} \equiv \text { total body compartment deposition fraction for the element, } \\
& D_{i} \equiv \text { total body compartment biological half time for the element, } \\
& f_{-} \quad \equiv \text { fraction of the element from blood to organ of reference. }
\end{aligned}
$$

Equation (5) applied where significant decay occurred at the deposition site, and not during transit or re-transit to the organ of interest. Values for compartment deposition fractions and compartment half times were obtainet from Ki78. Values for the remaining quantities were from ICRP59.

The dose equivalents to a specific organ or the total body were determined by using the source to target dose equivalent per unit cumulated activity parameters from Ki78. The total target dose equivalent was obtained by summation of the dosimetric contributions from all source organs. Several important modifications to the general procedure were made in order to compute individual dosimetric results. For each person, the source to target dose equivalent per unit cumulated activity was weighted by the ratio of a standard man's body mass relative to the actual mean body mass during the interval for which the dose equivalent was determined. In the case of ${ }^{137} \mathrm{Cs}$, the long term biological removal rate constant for the Marshallese population was highly dependent upon body mass (Mi81). Appropriate modifications to Eq. (2), (3), and (5) were made to reflect this dependence. Finally, for ${ }^{90} \mathrm{Sr}$ deposition in bone, $28 \%$ of the source to target dose equivalent per unit cumulated activity was assumed fron cancellous bone and $72 \%$ from cortical bone.

Figure 18 demonstrates the mean dose equivalent from ${ }^{137} \mathrm{Cs}$ for various age and sex groupings. The residence interval was from 1957 to 1980 for this population. The adolescents and persons above 50 years of age in 1957 maintained the lowest dose equivalent. Persons who died during this period were not included 


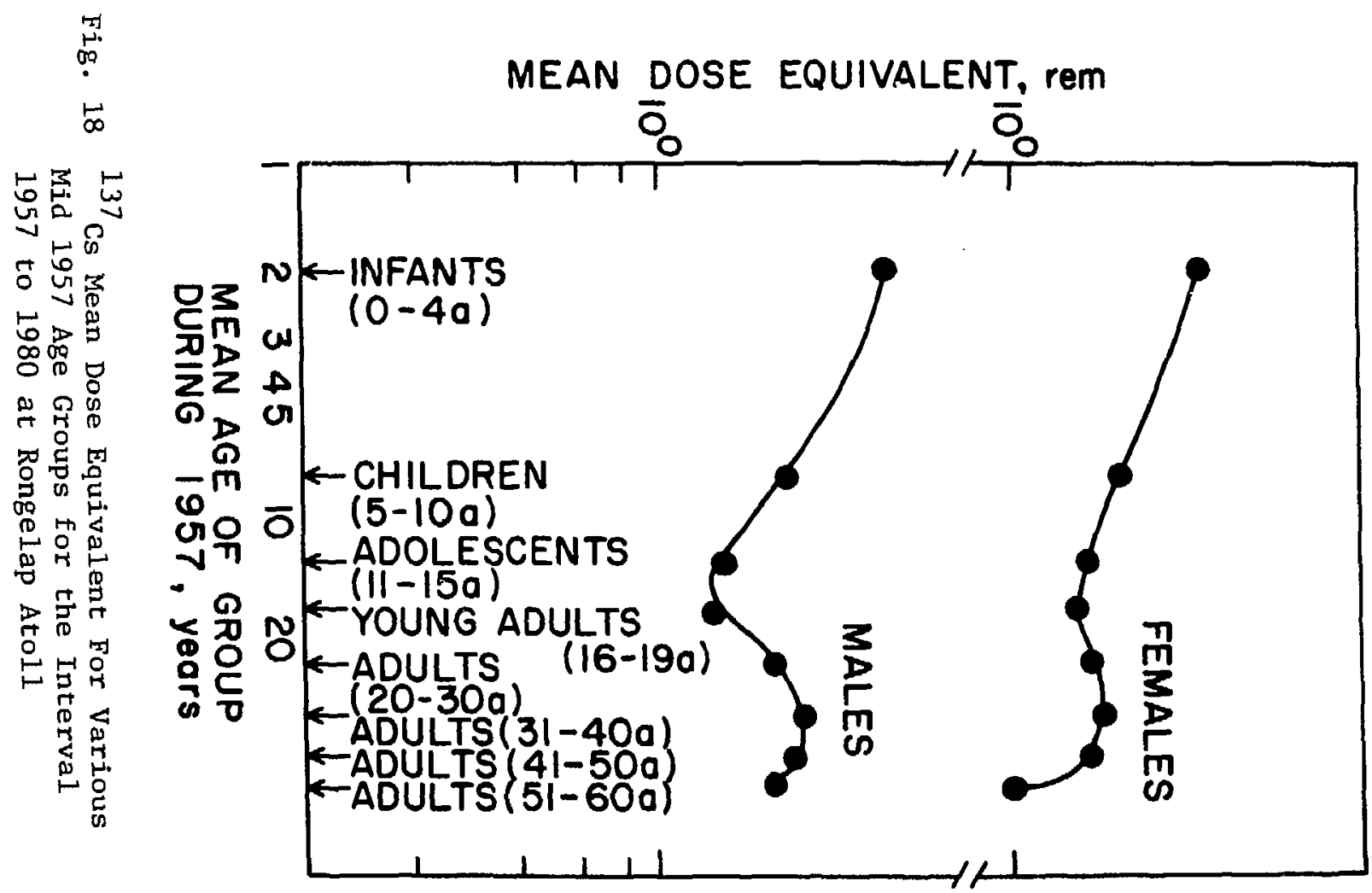


in the figure nor were they included in any dosimetric distributions for any of the nuclides. Thus all persons considered, regardless of initial age in 1957, experienced a 23 year exposure interval.

Figure 19 shows dose equivalent distributions according to age and sex for ${ }^{137} \mathrm{Cs}$ among the Rongelapese. The shape or the population distribution was skewed with a mean of 1.7 Rem and a maximum of 9.0 Rem. Thus the maximum was 5.3 times the mean value for ${ }^{137} \mathrm{Cs}$ on Rongelap. An examination of the subgroup distributions reveals that persons who were infants at the time of rehabitation at Rongelap also were the recipients of the higher doses. This was due to the combined effects of lower average body mass, a higher average ingestion rate, and more rapid turnover of ${ }^{137}$ Cs than that for adults or even children. The parameter having the greatest impact on the infant dose equivalent was body mass. The standard deviation for the adult male distribution was $49 \%$ of the mean dose equivalent, for adult females $43 \%$ of the mean dose equivalent, and for adolescents $47 \%$. Within a subgroup, the maximum observed dose equivalent was approximately twice the mean value for all distributions considered here.

Figure 20 shows mean dose equivalents as a function of returning age groups for ${ }^{65} \mathrm{Zn}$ on Rongelap. Adolescents, young adults, and adults 50 and up were the groups receiving lower total dose equivalents, while children and middle aged persons received higher dose equivalents during the residence interval. Measured ${ }^{65} \mathrm{Zn}$ data for persons who were infants at the return date were not reported in the publications by Conard et al.

Figure 21 shows the dosimetric distributions observed for members of the Rongelap population for ${ }^{65} \mathrm{Zn}$. Again the population overall exhibited a skewed distribution of dose with a maximum value nearly three times the mean. Children demonstrated higher doses than persons who were adults during the entire 23 

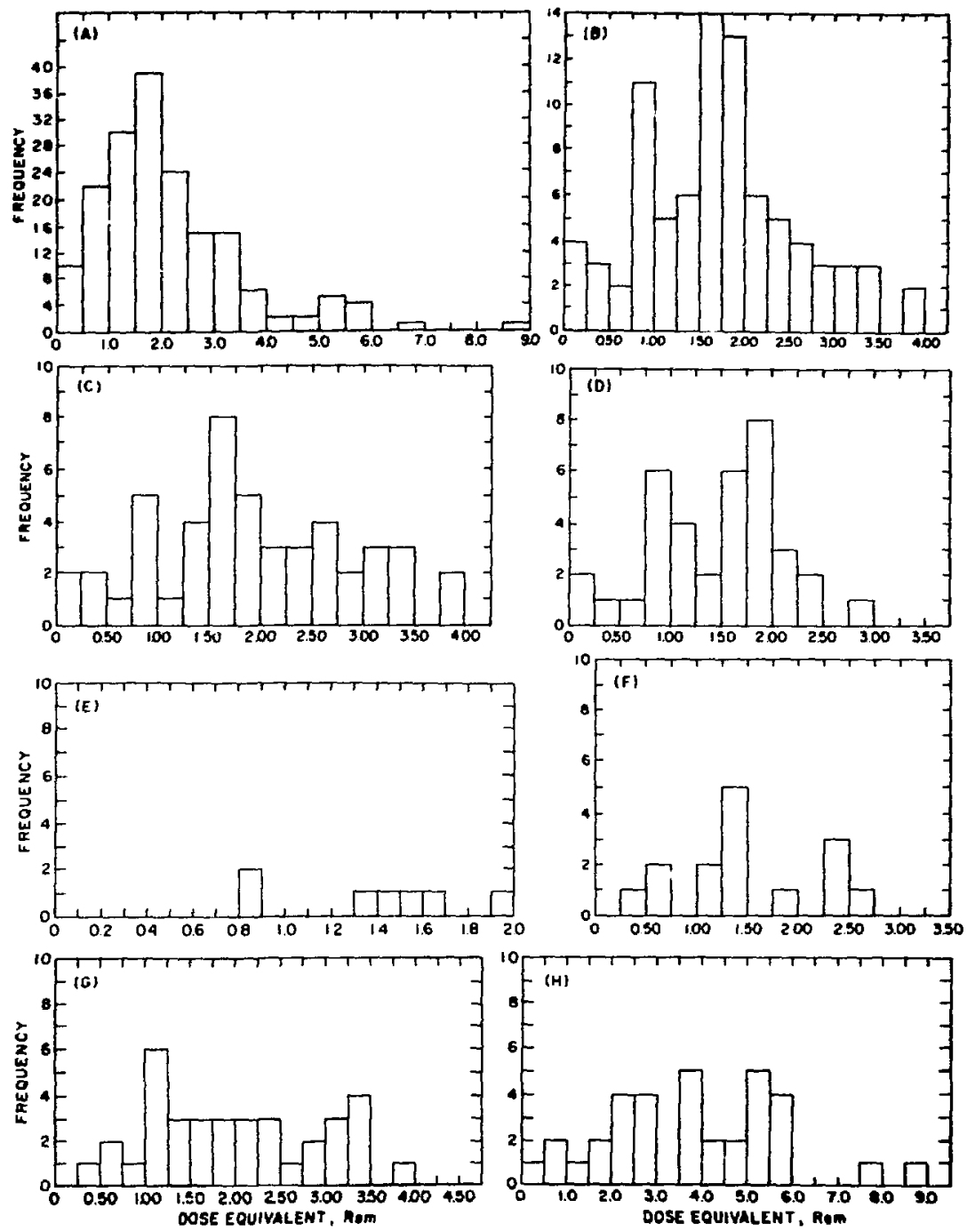

Fig. $19{ }^{137} \mathrm{Cs}$ Dose Equivalent to (A) All Residents (B) Adu1ts (C) Adult Males

(D) Adult Females (E) Young Adults

(F) Adolescents (G) Children and

(H) Infants on Rongelap 


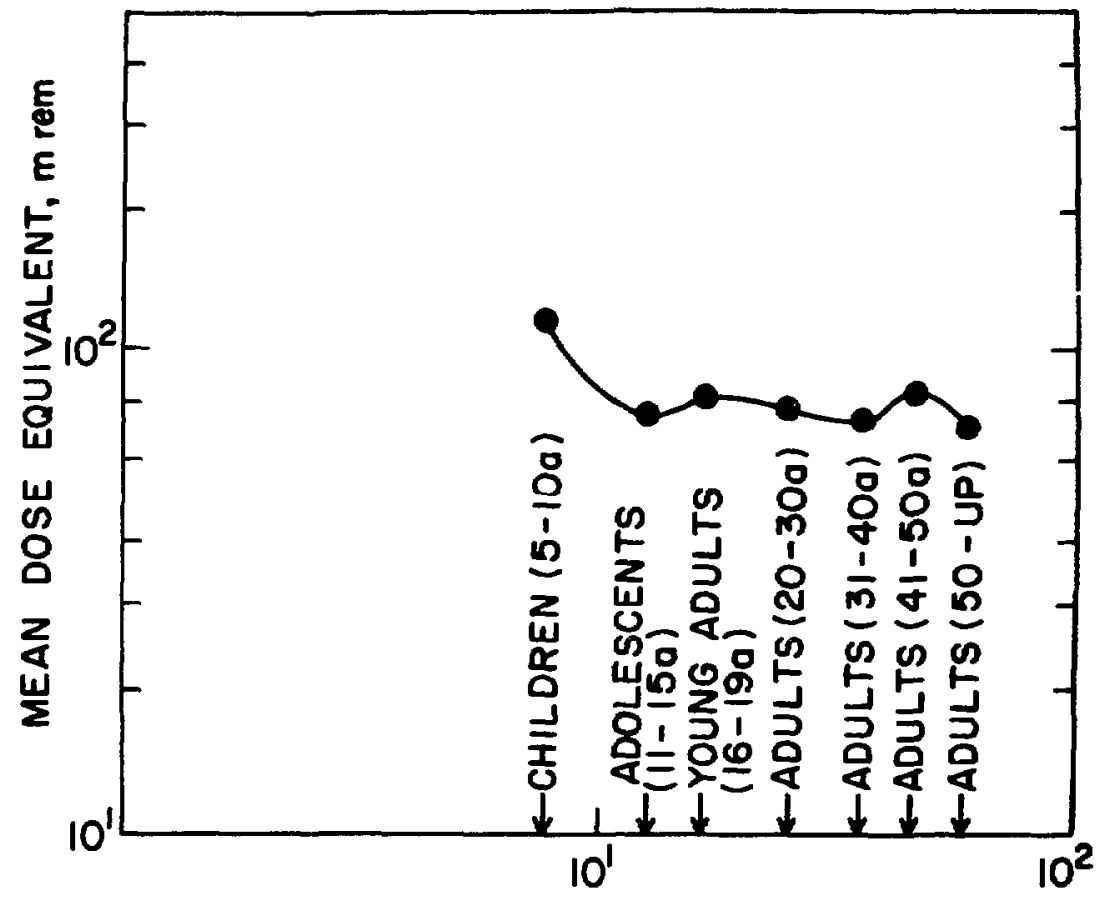

Fig. $20{ }^{65} \mathrm{Zn}$ Mean Dose Equivalent for Various Mid 1957 Age Groups for the Interval 1957 to 1980 at Rongelap Atol1 

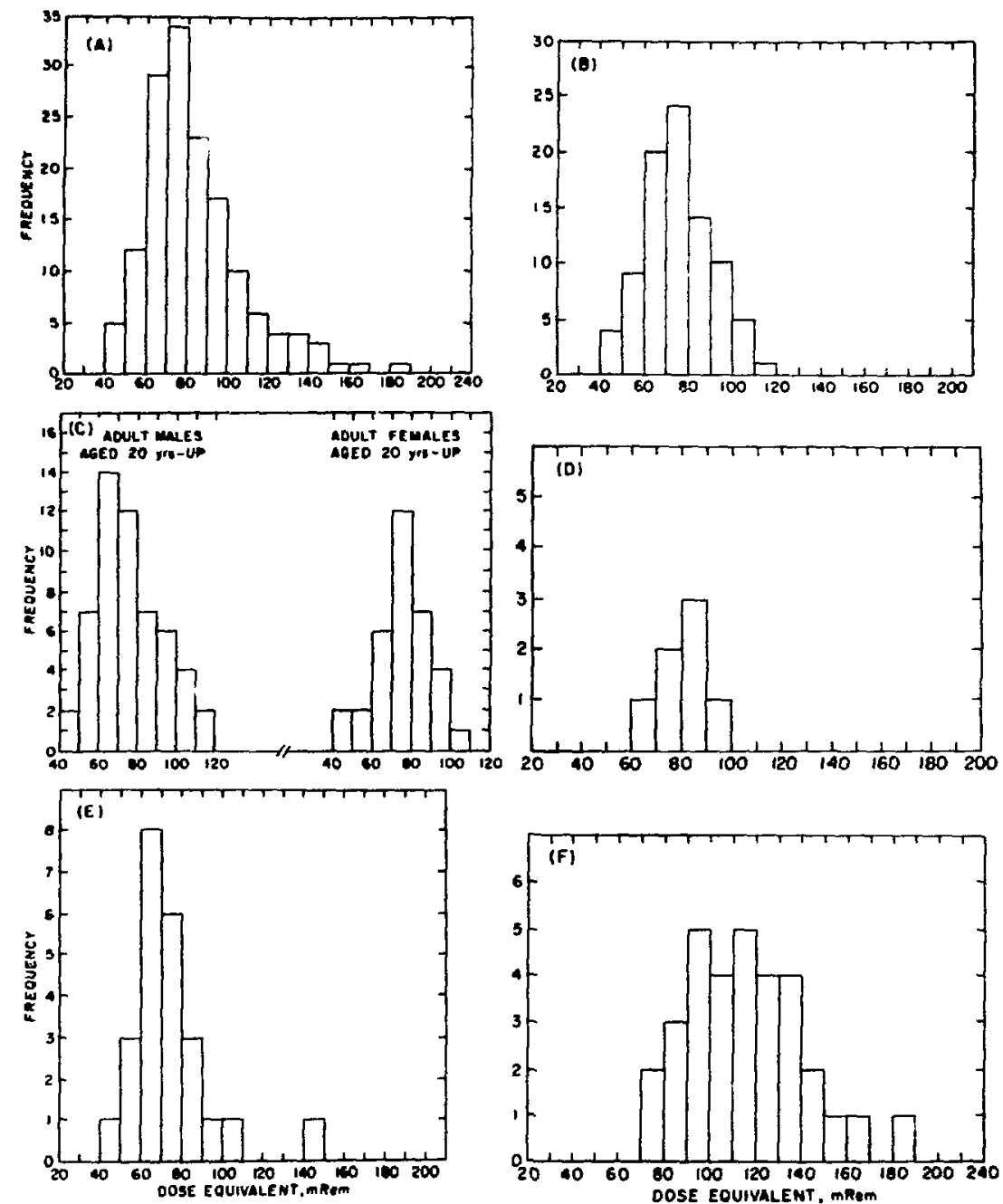

Fig $21{ }^{65}$ Zn Dose Equivalent to (A) All Residents

(B) Adults (C) Adult Males and Females

(D) Adolescents (E) Children and (F) Infants on Rongelap Atoll 
year period. The stan' rd deviation was in general $30 \%$ of the mean value for all age and sex subgroup distributions. This less pronounced variation may be due to the fact that ${ }^{65} \mathrm{Zn}$ measurements took place over a 3 year interval while ${ }^{90} \mathrm{Sr}$ and ${ }^{137} \mathrm{Cs}$ occurred over a 23 year interval and thus was contained in a more homogeneous population than were the longer lived nuclides.

Figures 22 and $23 a$ and $23 b$ summarize the ${ }^{90} \mathrm{Sr}$ dose equivalent results for individuals at Rongelap.

In this analysis, only the ingestion pathway was considered important. Some radioactivity would enter the body via the resuspension and direct inhalation pathways. It is known that for a given soil concentration of the stable naturally occurring analogs to the radionuclides considered here, the ratios of food and fluid intake to blood relative to airborne intake to blood, are as follows:

$$
\begin{array}{ll}
\mathrm{Co}>3000 & \mathrm{Zn}>130 \\
\mathrm{Fe}>550 & \mathrm{Sr}>10,000 \\
\mathrm{Cs}>400 &
\end{array}
$$

Thus, dietary intake of radioactive material is the principal pathway leading to internal deposition. This applies to most nuclides in the environment, however, there are notable exceptions including $\mathrm{I}, \mathrm{U}$, and $\mathrm{Pu}$.

\section{External Exposure}

A value of .73 rads in tissue of interest per röntgen, measured in air at one meter above the surface, was used to convert exposure in air to absorbed dose in tissue. The source was assumed to be an exponential distribution of ${ }^{137}$ Cs activity with depth in soil, typical of aged fallout (Be70). Because of the multidirectional nature of the source, variation of absorbed dose with depth of organ was minimal. Additionally, external doses were adjusted for living pat- 


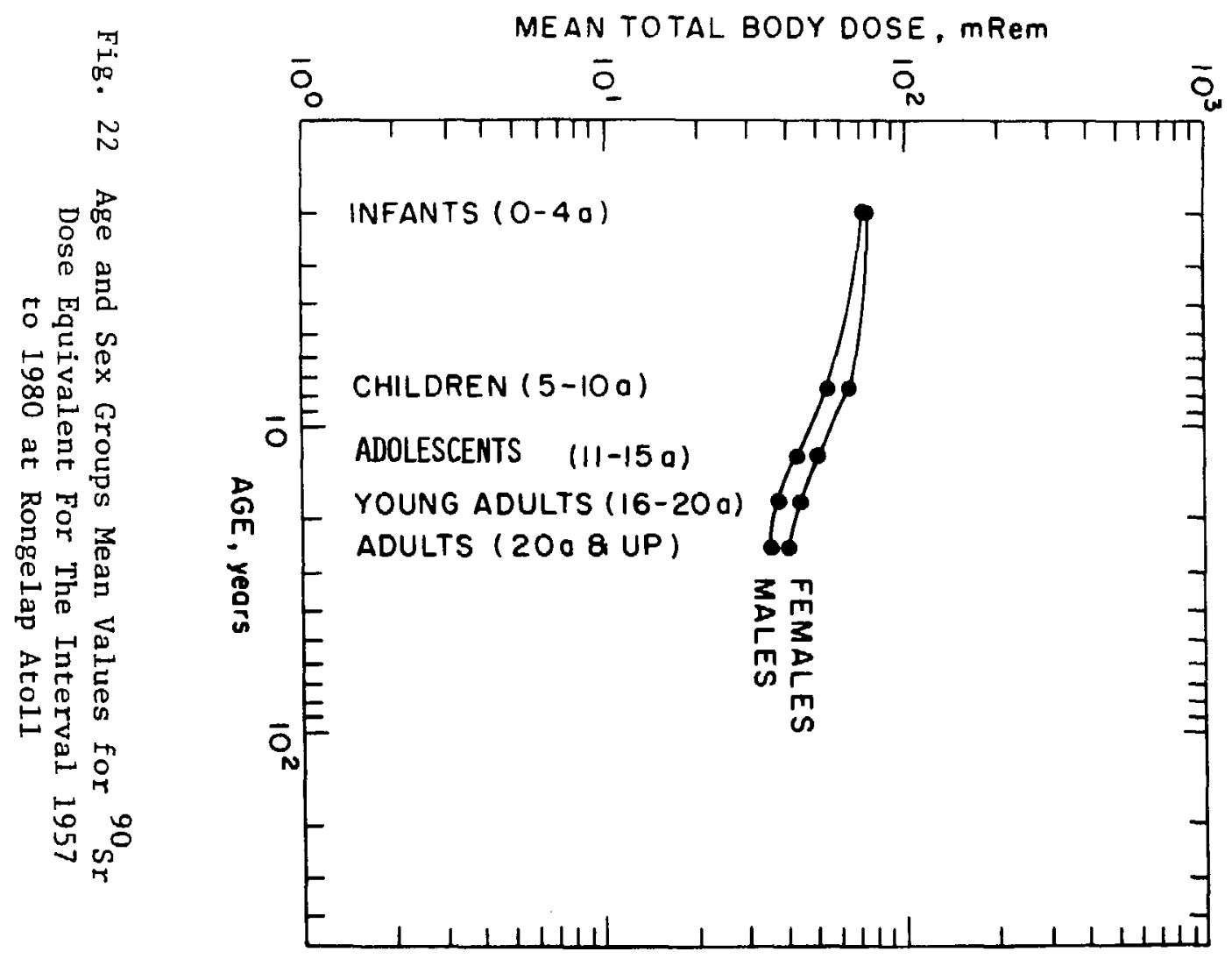



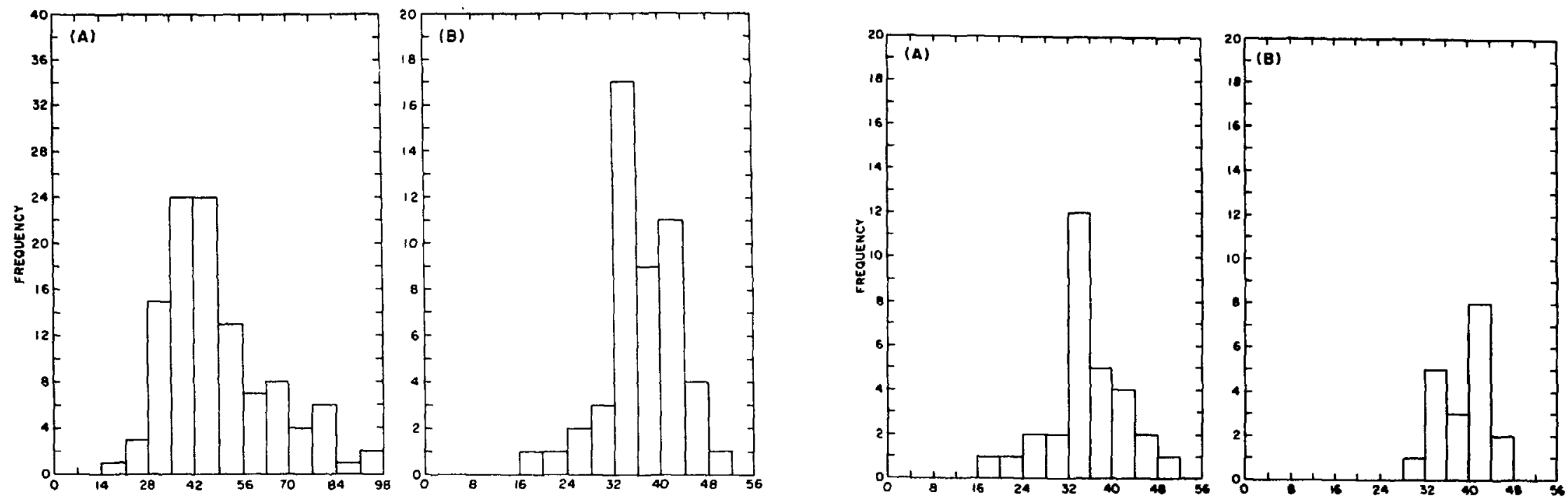

E
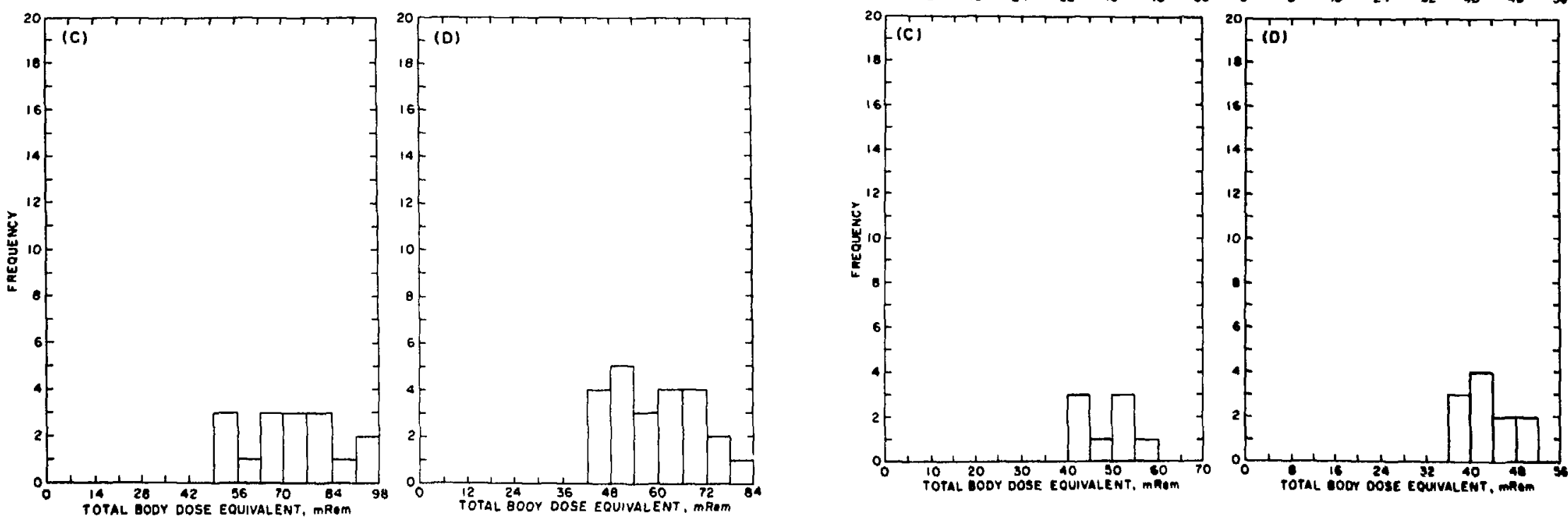

Fig. 23a

${ }^{90}$ Sr Dose Equivalent for (A) All Residents

(B) Adults (C) Infants and (D) Children on Rongelap

Fig. 23b ${ }^{90} \mathrm{Sr}$ Dose Equivalent for (A) Adu1t Males (B) Adult Females (C) Adolescents and (D) Young Adults on Rongelap 
tern variations since the atolls present a heterogeneous exposure rate environment (Gr77).

External exposure calculations are based on Figures 24 to 26 which were derived from data listed in $\mathrm{Cr} 56$, Sh57, Un59, and Gr77. The area under straight 1 ine portions of the curve was determined by

$$
x=\frac{R_{2} t_{2}-R_{1} t_{1}}{n+1} \text {, }
$$

where

$$
\begin{aligned}
& \mathrm{x} \equiv \text { external exposure during straight line interval, } \mathrm{mR}, \\
& \mathrm{R}_{2} \equiv \text { exposure rate at the end of the interval, } \mathrm{mRh}^{-1}, \\
& \mathrm{R}_{1} \equiv \text { exposure rate at the beginning of the interval, } \mathrm{mRh}^{-1}, \\
& \mathrm{t}_{2} \equiv \text { time post detonation at the end of interval, hours, } \\
& \mathrm{t}_{1} \equiv \text { time post detonation at the beginning of interval, hours, } \\
& \mathrm{n} \equiv \text { slope of a straight line. }
\end{aligned}
$$

Data from 11 detonations during May, June, and July of 1958 (Sh57) indicated a mean fallout deposition exponent of 18.8. This mean value was observed at Utirik, Rongelap, Parry, and Wotho and was applied to early time post detonation of BRAVO to ob tain the initial increasing exposure rate history shown on Figures 24 and 26 . This method yielded a fallout deposition period of 5.5 hours on Rongelap and 12 hours on Utirik. This time compares well with the original observations reported by the Marshallese and by U.S. Navy personnel stationed in the area (Sh57). Initial dose equivalents on "acute doses" are developed in greater detail in another report. 


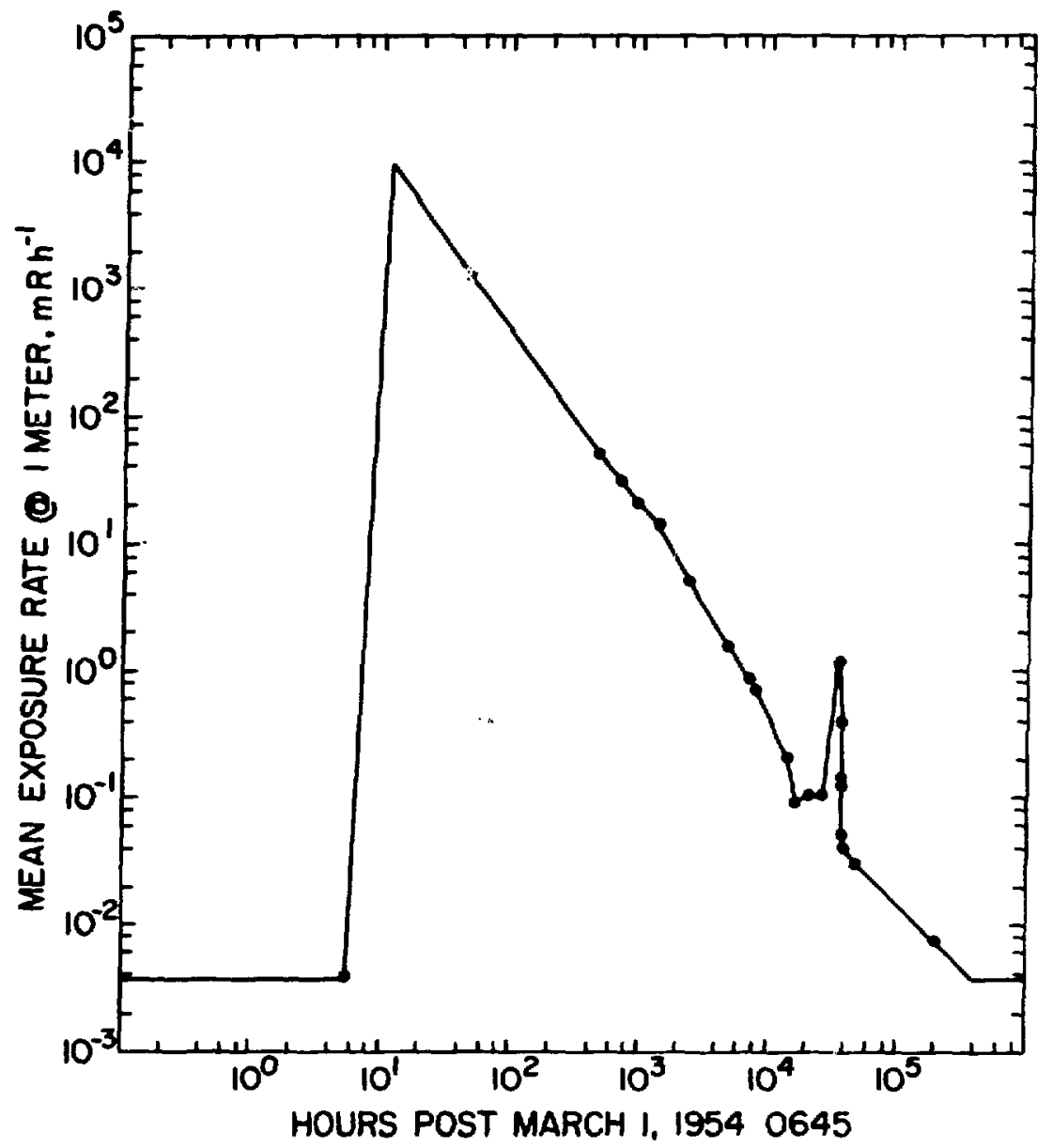

Fig. 24 Rongelap External Exposure Rate History Post Bravo 


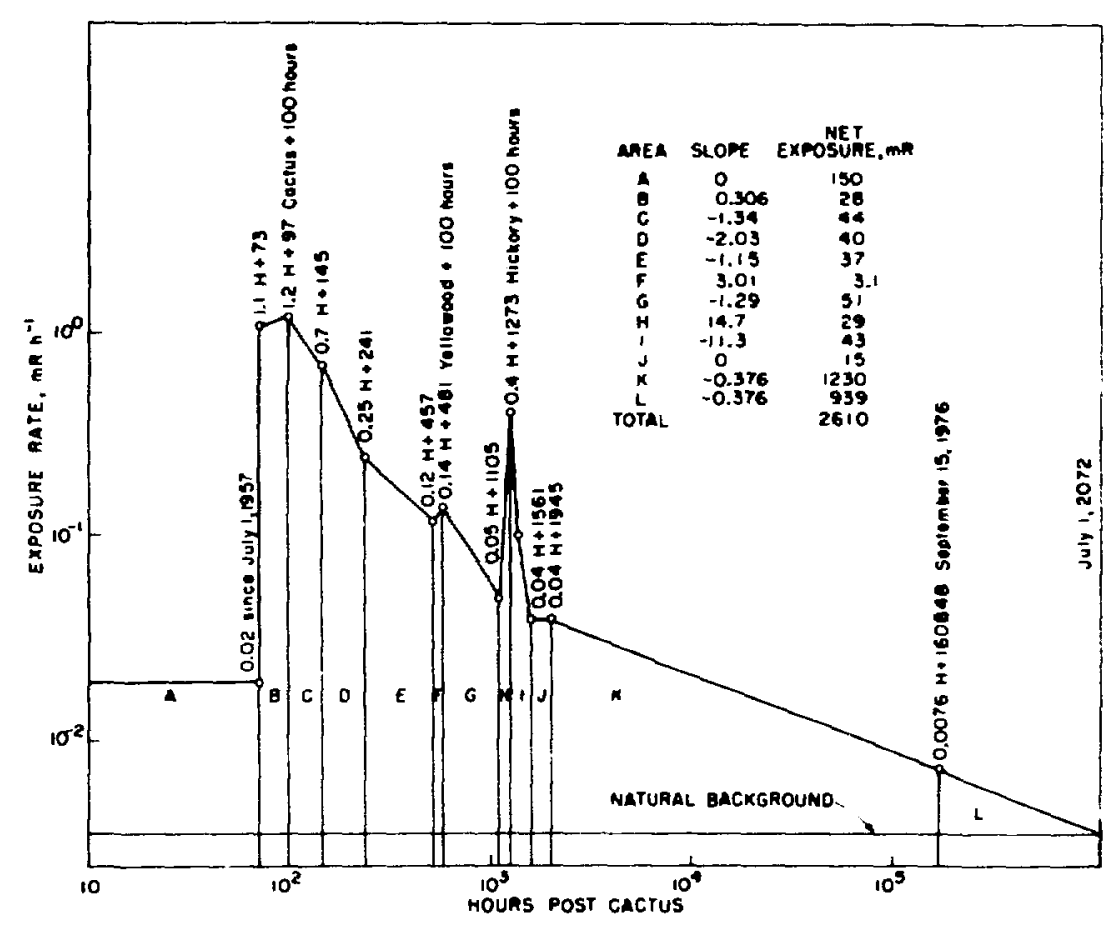

Fig 25 Rongelap External Exposure Rate History Post Cactus 


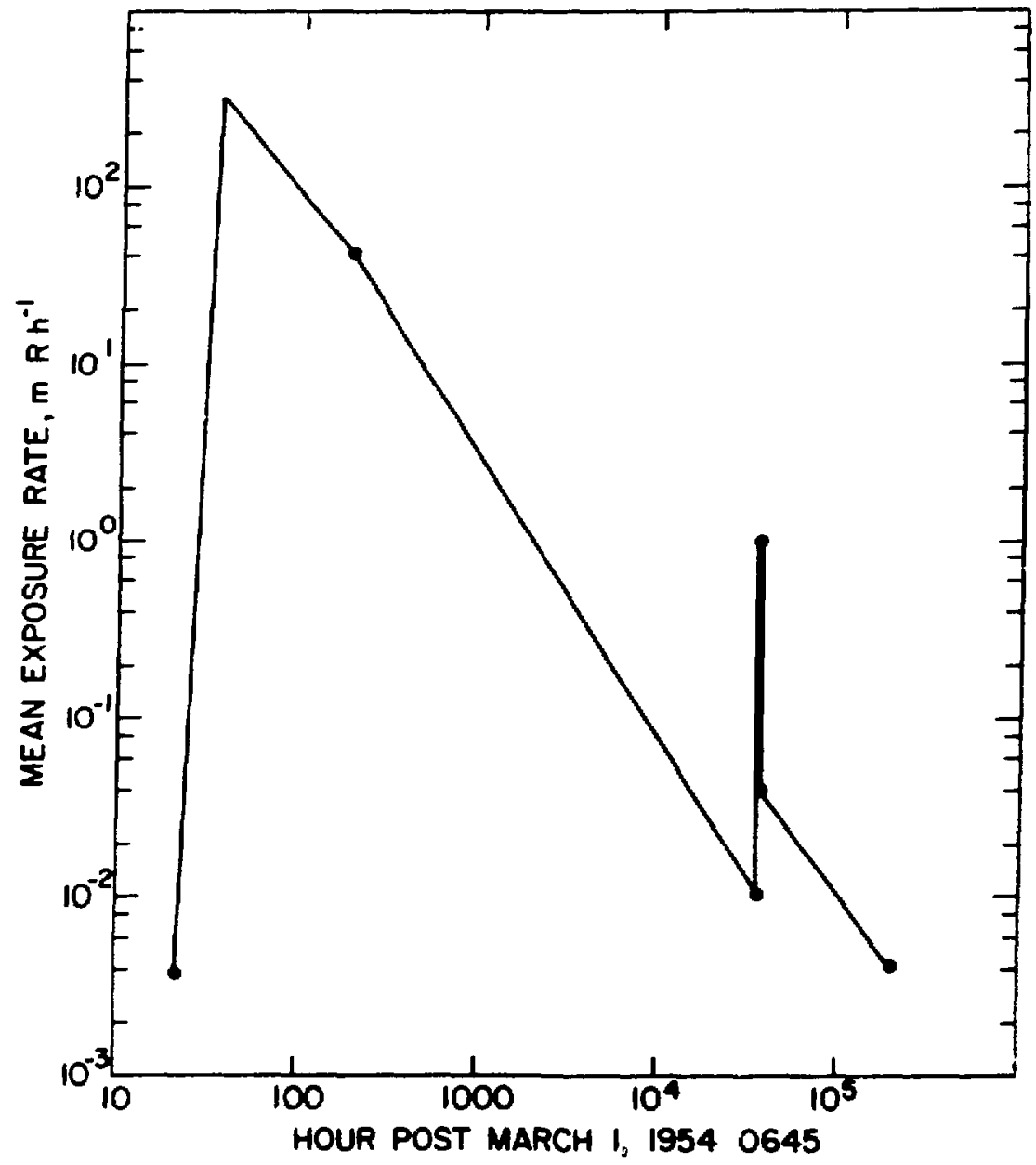

Fig. 26 Utirik External Exposure Rate History Post Bravo 
Figure 25 demonstrates the external exposure following the 1958 testing series. Since return to Rongelap followed 3 years after the BRAVo contamination, this series contributed in large part to the external exposure post return.

\section{SUMMARY}

The Castle BRAVO shot of March 1954 caused the contamination of the inhabited atolls Rongelap and Utirik. Evacuation from Rongelap commenced 50 hours after detonation and from Utirik 55 hours after detonation. During June 1954 and June 1957 the return of the Utirikese and Rongelapese occurred respectively. Body burden data for dosimetrically significant nuclides were obtained throughout the residence interval post return primarily by direct in vivo gamma spectroscopy and by indirect radiochemical analysis of urine and blood.

The dosimetric models used in this analysis were representative of a declining continuous uptake regime. Dietary decline of radioactivity included radioactive decay of the source and a conglomerate of other factors which might have included increased use of imported foods and weatherirg of the source. Dietary loss rate constants were estimated from sequential body burden data and were comparable for both atolls.

Variation in body burden history daca for a particular nuclide on a particular atoll was observed in whole body counting data and urine bioassay results. This was attributed principally to the statistical variation encountered when sma 11 groups are sampled from a heterogeneous group of body burdens in people, and in the case of urine bioassay additional variation was introduced during the laboratory analysis of samples.

Daily activity ingestion rates were determined for all measured radionuclides. In general, infants, children, and adults between 20 and 40 
years of age ingested more activity each day than did adolescents and persons greater than 40 years of age. Maximum deviation from the average value of the daily activity ingestion rate for members of an age subgroup was no greater than a factor of 3 . However, the population distributions illustrated a maximum factor of 5 times the mean activity ingestion rate value.

Dose equivalent rates post return were determined for members from both atolls. For Rongelap Atoll, the residents received approximately 100 to 200 mem per year during the first 5000 days post return from internal emitters. The principal contributing nuclide was ${ }^{137} \mathrm{Cs}$. For Utirik Atoll, the residents received up to 15 Rem per year during the first 400 days post return. The major contributing nuclides were ${ }^{65} \mathrm{Zn}$ and ${ }^{60} \mathrm{Co}$. Dose equivalent rates to the Utirikese from internal emitters fell below 500 mRem per year at approximately 1200 days post return.

The dose equivalent for population subgroups and for individuals was determined. Table 6 summarizes the results for the total body, thyroid, red marrow, testes, ovaries, lower large intestine wall, and liver. The catenary compartment model of Bernard and Hayes (Ber70) was used to determine doses to various segments of the gastrointestinal tract. The Utirikese received significantly more radiation dose from ${ }^{65} \mathrm{Zn},{ }^{60} \mathrm{Co}$, and ${ }^{55} \mathrm{Fe}$ than did the Rongelapese because of short mean residence times of these nuclides in the environment. ${ }^{90} \mathrm{~S}_{\mathrm{r}}$ doses to the Rongelapese were 2.5 time greater and ${ }^{137} \mathrm{Cs}$ doses 1.5 times greater than doses received by persons at Utirik. This occurred even though Utirik residents returned to their atoll 3 years earlier and somewhat reflects the degree to which Utirik was less contaminated than Rongelap. 
Table 6

Chronic Phase

Dose Equivalent Sumnary, Rem

Total Body

Thyroid

\begin{tabular}{lcccc} 
Nuclide & $\begin{array}{c}\text { Utirik } \\
\text { Adults }\end{array}$ & $\begin{array}{c}\text { Rongelap } \\
\text { Adults }\end{array}$ & $\begin{array}{c}\text { Utirik } \\
\text { Adults }\end{array}$ & $\begin{array}{c}\text { Rongelap } \\
\text { Adults }\end{array}$ \\
\hline $90 \mathrm{Sr}$ & .012 & .027 & .00075 & .0017 \\
$55 \mathrm{Fe}$ & .033 & .023 & .059 & .042 \\
$137 \mathrm{Cs}$ & 1.1 & 1.7 & 1.6 & 2.4 \\
$60 \mathrm{Co}$ & .51 & .014 & .36 & .010 \\
$65 \mathrm{Zn}$ & 13. & .076 & 11. & .067 \\
Internal & 14. & 1.9 & 13. & 2.5 \\
External & 3.2 & 2.0 & 3.2 & 2.0 \\
Total & 17. & 3.9 & 16. & 4.5
\end{tabular}

Red Marrow

Testes-Ovaries

$\begin{array}{ccccc}90 \mathrm{Sr} & .054 & .12 & .00075-.00075 & .0017-.0017 \\ 55 \mathrm{Fe} & .060 & .042 & .058-.062 & .074-.043 \\ 137 \mathrm{Cs} & 1.7 & 2.6 & 1.5-1.7 & 2.3-2.6 \\ 60 \mathrm{Co} & .63 & .018 & .44-1.8 & 0.12-.050 \\ 65 \mathrm{Zn} & 17 . & .10 & 11 .-16 . & .069-.099 \\ \text { Interna } & 20 . & 2.9 & 13 .-20 . & 2.5-2.8 \\ \text { External } & 3.2 & 2.0 & 3.2 & 2.0 \\ \text { Total } & 23 . & 4.9 & 17 .-23 . & 4.5-4.8\end{array}$

Lower Large

Intestine Wa11

Liver

$\begin{array}{ccccc}90 & \mathrm{Sr} & .57 & .00067 & .0015 \\ 55 \mathrm{Fe} & .23 & .047 & .12 & .080 \\ 137 \mathrm{Cs} & .067 & .90 & 1.8 & .7 \\ 60 \mathrm{Co} & .59 & .13 & .091 & .79 \\ 65 \mathrm{Zn} & 4.7 & 1.7 & 17 . & .14 \\ \text { Internal } & 15 . & 21.0 & 19 . & 2.0 \\ \text { External } & 3.2 & 3.8 & 3.2 & 5.0 \\ \text { Total } & 24 . & 22 . & & \end{array}$




\section{REFERENCES}

Be70 Bennett, B.G., 1970, Estimation of gonadal absorbed dose due to environmental gamma radiation, Health Phys. 19, 757-67.

Be72 Beasley, T.M., Held, E.E., and Conard, R.A., 1972, Iron-55 in Rongelap people, fish and soils, Health Phys. 22, 245-50.

Ber70 Bernard, R.S. and Hayes, R.L., 1970, Dose to various segments of the gastrointestional tract, Pro. Symp. Med. Radionuclides: Radiation Dose and Effects.

Co57 Conard, R.A., et al., 1958, March 1957 Medical Survey of Rongelap and Utirik People Three Years After Exposure to Radioactive Fallout, BNL 501 .

Co59 Conard, R.A., et al., 1959, Medical Survey of Rongelap People, March 1958, Four Years After Exposure to Fallout, BNL 534.

Co60 Conard, R.A., et a1., 1960, Medical Survey of Rongelap People Five and Six Years After Exposure to Fallout (With an Addendum on Vegetation), BNL 609 .

Co62 Conard, R.A., et al., 1962, Medical Survey of Rongelap People Seven Years After Exposure to Fa11out, BNL 727.

Co63 Conard, R.A., et al., 1963, Medical Survey of Rongelap People Eight Years After Exposure to Fallout, BNL 780 .

Co65 Conard, R.A., et a1., 1965, Medical Survey of the People of Rongelap and Utirik Islands Nine and Ten Years After Exposure to Fallout Radiation (March 1963 and March 1964), BNL 908. 
Co67 Conard, R.A., et a1., 1967, Medical Survey of the People of Rongelep and Utirik Islands Eleven and Twelve Years After Exposure to Fallout Radiation (March 1965 and March 1966), BNL 50029.

Co70 Conard, R.A., et a1., 1970, Medical Survey of the People of Rongelap and Utirik Islands Thirteen, Fourteen and Fifteen Years After Exposure to Fallout Radiation (March 1967, March 1968, and March 1969), BNL 50220 .

Co75 Conard, R.A., et al., 1975, A Twenty-Year Review of Medical Findings in a Marshallese Populations Accidentally Exposed to Radioactive Fallout, BNL 50424 .

Co80a Conard, R.A., et al., 1980, A Twenty-Five Year Review of Medical Findings in a Marshallese Population Accidentally Exposed to Radioactive Fa1lout, BNL, in press.

CoBob Conard, R.A., private communication.

Cr56 Cronkite, E.P., Bond, V.P., and Dunham, C.L., 1952, A Report on the Marshallese and Americans Accidentally Exposed to Radiation from Fall out and a Discussion of Radiation Inju.y in the Human Being, U.S. Atomic Energy Commission, TID 5358.

Gi72 Glasstone, S., Editor, 1957, The Effects of Nuclear Weapons, Defense Atomic Support Agency, Department of Defense.

Gr77 Greenhouse, N.A., and Miltenberger, R.M., 1977, External Radiation Survey and Dose Predictions for Rongelap, Utirik, Rongerik, Ailuk and Wotje Ato11s, BNL 50797.

ICRP59 Recommendations of the International Commission on Radiological Protection, 1959, ICRP Publication 2, Report of Comnittee II on Permissible Dose for Internal Radiation. 
ICRP68 Recommendations of the International Comission on Radiological Protection, 1968, ICRP Publication 10, Report of Committee IV on Evaluation of Radiation Doses to Body Tissues from Internal Contamination due to Occupational Exposure.

ICRP69 Recommendations of the International Commission on Radiological Protection, 1969, ICRP Publication 10A, Report of Committee IV on the Assessment of Internal Contamination Resulting from Recurrent or Prolonged Uptakes .

ICRP74 Recommendations of the International Commission on Radiological Protection, 1974, ICRP Publication 23, Report of the Task Group on Reference Man.

ICRP 79 Recommendations of the International Commission on Radiological Protection, 1979, ICRP Publication 30, Report of Committee II on Limits for Intakes of Radionuclides by Workers.

Ja64 James, R.A., 1964, Estimate of Radiation Dose to Thyroids of the Rongelap Children Following the BRAVO Event, UCRL-12273.

Ki75 Killough, G.G., Dunning, D.E., Bernard, S.R., and P1easant, J.C., 1978, Estimates of Internal Dose Equivalent to 2.2 Target Organs for

Radionuclides Occurring in Routine Releases from Nuclear Fu11-Cyc1e Facilities, NUREG/CR-0150, ORNL/NUREG/TM190.

Le80 Lessard, E.T., Mi 1tenberger, R.P., and Greenhouse, N.A., 1980, Dietary Radioactivity Intake from Bioassay Data: A Model Applied to ${ }^{137}$ Cs Intake by Bikini Island Residents, Health Phys. 39, 177-83.

Mi80 Milcenberger, R.P., Greenhouse, N.A. and Lessard, E.T., 1980, Whole Body Counting Results from 1974 to 1979 for Bikini Islands Residents, Health Phys. 39, 395-407. 
Mi81 Mi ltenberger, R.P., Lessard, E.T., and Greenhouse, N.A., 1981, 60 Co and 137 Cs Long Term Biological Removal Rate Constants for the Marshallese

Population, Hea1th Phys. 39, in press.

Na80 Naidu, J., Greenhouse, N., and Knight, J., 1980, Marsha11 Islands: A

Study of Diet and Living Patterns.

Sh57 Sharp, R., and Chapman, W., 1957, Exposure of Marshall Islanders and

American Military Personnel to Fallout, Naval Medical Research Institute, WT -938 .

Un59 United States Public Health Service, 1959, Report of Public Health Ser-

vice Off-Site Radiological Monitoring Data, Operation Hardtack Phase I

1958. 